\title{
The influence of industry downturns on the propensity of product versus process innovation
}

\author{
Luca Berchicci*, Christopher L. Tucci*** and Cristiano Zazzara ${ }^{\dagger}$
}

\begin{abstract}
This article sheds light on how industry fluctuations affect firms' propensity to innovate. We test two seemingly conflicting arguments that suggest how firms are more or less inclined to engage in innovation activities during industry fluctuations. By studying a panel of 622 Italian manufacturing firms during the period 1995-2003, we show how differentiating between product and process innovation may help reconcile the theory of opportunity cost of innovation with the cash-flow effect argument. We find that industry downturns are related to product and process innovation in different ways: firms tend to invest in product innovation rather than process innovation in downturns. The findings have implications for both theory (showing when the opportunity cost of innovation dominates) and research design (showing the importance of both the input and output measures in innovation studies and how they might influence the results).
\end{abstract}

JEL classification: E32, L60, O470, 0310.

\section{Introduction}

The global economic crisis of 2008-2009 has shown once again how environmental factors and market changes seriously influence industry dynamics and firm strategy. How firms react and respond to industry changes and fluctuations by adapting their

\footnotetext{
${ }^{\star}$ Luca Berchicci, Erasmus University Rotterdam School of Management, PO Box 1738, 3000 DR Rotterdam, The Netherlands. e-mail: berchicci@rsm.nl

${ }^{*}$ Christopher L. Tucci, Ecole Polytechnique Fédérale de Lausanne (EPFL), Station 5, CH-1015 Lausanne, Switzerland. e-mail: christopher.tucci@epfl.ch

${ }^{\dagger}$ Cristiano Zazzara, RiskMetrics Group, Ten Bishops Square, London E1 6EG, United Kingdom. e-mail: cristiano.zazzara@gmail.com

"Main author for correspondence.
} 
innovation strategies is still a relevant question both for scholars and practitioners, as such changes affect firms' profitability in the long term (McGahan and Porter, 1999). The main purpose of this study is therefore to identify how certain environmental factors influence the innovative behavior of manufacturing firms. In particular, we focus on how industry downturns influence manufacturing firms' realization of innovation activities.

Previous research has attempted to explain and predict the relationship between industry fluctuations or market changes and firms' propensity to innovate. On one hand, countercyclical arguments predict that in an industry downturn, firms tend to invest in innovation activities owing to the diminished rents of existing activities (Geroski and Walters, 1995). On the other hand, pro-cyclical arguments suggest that firms tend to retrench innovation activities during industry downturns owing to the limited resources and perceived high risk of innovation undertakings. So far, the empirical evidence has been ambiguous. Some scholars find a positive relationship between industry downturns and innovation activities (Nickell et al., 2001, process innovation only), others find non-existent associations (McGahan and Silverman, 2001; Saint-Paul, 1993), while still other researchers argue that positive business or industry fluctuations trigger innovation activities (Geroski and Walters, 1995).

We test these seemingly competing arguments by investigating how industry downturns influence firms' propensity to engage in product and process innovation by using data from a well-known Survey on Italian Manufacturing Firms (SIMF).

Our research advances the literature in two ways. First, our results suggest that theories that try to explain firm's innovation propensity need to clearly separate the influence of environmental factors on product versus process innovation. Our findings suggest that during industry downturns, Italian manufacturing firms engage in product innovation while holding back on process innovation. We provide a novel theoretical explanation by bridging opportunity cost theory with the cash flow effect argument. Second, we show how spurious results may be generated by lumping product and process innovation together. We suggest that previous ambiguous results may be due to the heterogeneous effects of industry fluctuations on the types of innovation; in other words, when different measures of innovation are used (some process, some product, some combination of the two), it is difficult to predict in which direction different environmental factors will work. As a number of empirical studies use proxies of innovation activities without clearly distinguishing the type of innovation, these practices may contribute to a lack of uniform results in the literature.

The article is organized as follows. First, we provide definitions of product and process innovation. Second, a brief review of the literature is presented and finalized by proposing two sets of conflicting hypotheses. Next, we provide a description of the survey data used for this study and of the empirical models used for the analysis. After reporting and discussing the results, we conclude the article by emphasizing its contribution and stating its limitations. 


\section{Theory and hypotheses}

\subsection{Product and process innovation}

The importance of innovation as a crucial means to create and maintain economic growth and sustainable competitive advantage has been largely acknowledged (e.g. Drucker, 1985; Schumpeter, 1934). Schon (1967) describes the corporation as a miniature nation where the weapons are products and processes, its battlefield is the marketplace, and innovation is essential to engage in this "war." Nevertheless, there is no consensus in defining "innovation" exclusively (for a review, see Garcia and Calantone, 2002). A general and early definition of innovation is that of Schumpeter: "the commercial or industrial application of something new-a new product, process or method of production; a new market or source of supply; a new form of commercial, business or financial organization" (Schumpeter, 1934: 73). Starting from this definition, we generally refer to two distinctive innovation activities of a firm: product and process innovation. The former usually refers to a new product, invention or artifact that is introduced into the market and put into use (Garcia and Calantone, 2002; Schon, 1967). The latter is defined as new factors (systems, equipment, and human resources) introduced in an organization to increase product quality, improve methods of production, or reduce production costs (Damanpour, 1991; Kurkkio et al., 2011; Pisano, 1990; Reichstein and Salter, 2006). How industry downturns might affect the propensity of firms to engage in either product or process innovation is the aim of the next section.

\subsection{Industry level fluctuations}

Previous research has investigated how firms innovate in different phases of industry cycles (e.g. Windrum, 2005). Theory suggests and empirical evidence demonstrates that product innovation is the predominant form of innovation when an industry emerges and grows, whereas in the mature, declining, and/or "systemic" phase of an industry, the dominant form is process innovation (Abernathy and Utterback, 1978; Anderson and Tushman, 1990; Gort and Klepper, 1982; Jovanovic and MacDonald, 1994; Klepper, 1997; Suarez and Utterback, 1995). At the industry level, cycles occur over a long period, where an emergent phase is followed by a phase of growth and finally by maturity and decline (Gort and Klepper, 1982; Jovanovic and MacDonald, 1994). These cycles are rarely repetitive in a single industry, as an industry phase may last for years if not decades.

Rather than on long-term industry cycles, the focus of this article is on shorter-term industry fluctuations. We define industry fluctuations as changes in demand occurring within a 1- to 3-year period during which the industry may experience downturns or upturns. These industry fluctuations can be repetitive in a single industry. For example, the software industry experienced industry fluctuations in terms of rapid growth in the number of firms and in demand in the late 1990s, followed by a period of decline (the 
bursting of the dot.com bubble). From an industry cycle perspective, however, the software industry has experienced a phase of sustained growth during the past decades. Our definition of industry fluctuations is similar to business cycles in a specific industry context. The difference resides in the unit of analysis. Although business cycles usually capture changes in the overall economy, industry fluctuations are industryspecific — changes in demand within industry sectors.

Therefore this article attempts to answer the question: how do industry downturns influence a firm's propensity to innovate? We assume a "demand pull" perspective where changes in the environment (industry fluctuations) affect this propensity (Scherer, 1982; Schmookler, 1966). As Geroski and Walter (1995) demonstrate in their work, there could be a causal relationship between industry fluctuations and innovation activities (and not vice versa). From this perspective, there are two conflicting arguments that state the type of relationship between industry fluctuations and innovation activities.

The first argument is based on analogues to the opportunity cost of innovation. As explained by Geroski and Walters (1995), during a cyclical downturn, the rents from a firm's current activities usually decrease (Arrow, 1962), and if this loss is larger than the relative returns to be gained from implementing new products or processes, firms have incentives to introduce new innovations (Geroski and Walters, 1995; SaintPaul, 1997). Moreover, as environmental conditions change, firms need to reallocate and divert resources strategically by changing current activities or structures and setting new activities (Hall, 1991b; Penrose, 1959). A downturn in an industry could trigger firms to restructure their relatively less profitable activities (Kleinknecht, 1984). For example, Hall (1991a) suggests that firms invest in innovation activities and redeployment of organizational resources when there is a contraction in demand. These scholars suggest a counter-cyclical argument that implies a positive relationship between an industry downturn and innovation activities.

A second argument, contrary to the first one, is based on analogues to a cash-flow effect. Industry downturns reduce cash flow and make it difficult for a firm to finance and invest in new innovation activities. On the contrary, favorable market conditions, increased profitability, deep cash flow, and greater demand imply greater incentives for firms to engage in innovation activities. For example, prior research on R\&D output emphasizes this pro-cyclical behavior (Himmelberg and Petersen, 1994). Others argue that firms introduce new technologies in upturns to capture high profits (Shleifer, 1986). This second perspective suggests that there is a negative relationship between an industry downturn and innovation activities (i.e. pro-cyclical behavior).

Previous empirical reseach has focused on the relation between business cycles and productivity growth, yet has rarely studied the relation between industry fluctuations and innovation activities, and the limited evidence has shown unclear findings. For example, Nickell, Nicolitsas, and Patterson (2001) find that UK manufacturing firms introduce productivity-improving innovations during downturns. On the other hand, Geroski and Walters (1995) find that industry fluctuations 
positively influence innovation activities by studying UK patents and innovation for a 40-year period. Looking at US firm R\&D expenditures during the period 19561996, Rafferty (2003) seems to confirm pro-cyclical behavior. However, Saint-Paul (1993: 880) finds "very little evidence of any pro- or countercyclical behavior" of $\mathrm{R} \& \mathrm{D}$ activity (measured by $\mathrm{R} \& \mathrm{D}$ expenditures). Taking a longer view of the cycles, McGahan and Silverman (2001) attempt to link different industry cycles and different types of innovation. By examining various industries for a 13-year period, they claim that there is not a significant difference between innovation activities in mature and emerging industries.

Given the lack of clear empirical evidence, we are agnostic on which approach has more explanatory power. We also note that the different works cited earlier in the text use different measures to operationalize "innovation," and we would like to explore the distinction between two types of innovation in our theory development. Therefore, we put forward two sets of conflicting hypotheses based on variants and extensions of the two aforementioned arguments on the effect of industry downturn on a firm's propensity to engage in product innovation and process innovation, respectively. Table 1 presents the outline of these arguments.

\subsubsection{Countercyclical product innovation investment}

According to the first argument, and as depicted in the upper left quadrant of Table 1, engaging in innovation activities has lower opportunity costs during an industry downturn than it would have during an upturn owing to the lower returns from existing products. Geroski and Walters (1995) emphasize that these innovation activities center on new products, as opposed to incremental improvements in existing products. Moreover, it is likely that firms have excess capacity-in terms of manufacturing, labor, and distribution - that in turn could provide an incentive to deploy current underused resources for new product innovation at lower marginal costs. Furthermore, if such complementary assets were depreciating, it may make sense for a firm to seek out another use, which may involve moving into a new market (King and Tucci, 2002; Mitchell, 1989).

According to the literature on strategic diversification (e.g. Ansoff, 1958), given a lower value of the current product set, firms could engage in new product innovation to explore new markets or market niches where demand might be growing and to diversify their product portfolio while reducing the risk of decreasing returns. Furthermore, engaging in new product development could give those firms the opportunity to have an advantage when demand increases later on, either because the product is at a more advanced stage or the necessary complements have been developed in the interim, thus giving the firm some advantages. According to this argument, one would expect that:

H1a: there is a positive relationship between an industry downturn and firms' propensity to engage in product innovation. 
Table 1 Effects of industry downturns on a firm's propensity to innovate

\begin{tabular}{|c|c|c|}
\hline During a downturn & Product innovation & Process innovation \\
\hline $\begin{array}{l}\text { Countercyclical argument } \\
\text { Reasons to pursue }\end{array}$ & $\begin{array}{l}\text { - Lower opportunity costs owing } \\
\text { to lower returns from existing } \\
\text { products } \\
\text { - Search for new market where } \\
\text { demand might be growing } \\
\text { - Risk reduction through } \\
\text { diversification } \\
\text { - Pre-emption on new products }\end{array}$ & $\begin{array}{l}\text { - Cost-saving process innovations } \\
\text { could allow firms to reap profits } \\
\text { despite the lower demand } \\
\text { - Productivity-improving activities } \\
\text { provide firms with cost advan- } \\
\text { tage when the demand recovers }\end{array}$ \\
\hline $\begin{array}{l}\text { Pro-cyclical argument } \\
\text { Reasons not to pursue }\end{array}$ & $\begin{array}{l}\text { - Owing to cash flow constraints, } \\
\text { firms are less prone to develop } \\
\text { new products } \\
\text { - Larger risk of failure owing to } \\
\text { uncertainty on the duration of } \\
\text { the downturn and lack of confi- } \\
\text { dence on consumer demand } \\
\text { - Customers may be able to ap- } \\
\text { propriate more benefit when } \\
\text { there are fewer of them and } \\
\text { demand is lower }\end{array}$ & $\begin{array}{l}\text { - Fewer incentives for productivity- } \\
\text { enhancing activities for products } \\
\text { whose value is depreciated } \\
\text { - Investment could be lost if cur- } \\
\text { rent products do not meet future } \\
\text { demand } \\
\text { - Low return on investment owing } \\
\text { to lower demand }\end{array}$ \\
\hline
\end{tabular}

\subsubsection{Pro-cyclical product innovation investment}

Reasoning based on the second argument (lower left quadrant of Table 1) would expect that during an industry downturn, firms would be constrainted in their financial resources and thus less prone to engage in product innovation activities. Moreover, as the duration and persistence of the downturn are not well known, firms may be uncertain about future development and thus tend to postpone large decisions in product innovation investment (Dixit and Pindyck, 1994). In other words, if the length of time it takes to develop and launch a new product is known, but the demand conditions at the launch are highly uncertain, it may be better to hold off making large investments in product development (Yang et al., 2004). Relatedly, owing to the currently lower demand, firms could perceive product innovation as a risky undertaking because it requires confidence in consumer demand. Finally, firms may be more able to appropriate the rents from product innovations when market conditions are more favorable, and there are more customers willing to buy. According to this logic, one would expect that they would tend to retrench:

H1b: there is a negative relationship between an industry downturn and firms' propensity to engage in product innovation. 


\subsubsection{Countercyclical process innovation investment}

As shown in the upper right quadrant of Table 1, there are several related reasons for why process innovation investment may proceed in a countercyclical fashion. Some of them are related to product innovation, as, in many cases, firms that develop new products may need to simultaneously develop new processes to complement them (Pisano, 1991), given their strong interdependency (Milgrom and Roberts, 1995). For example, in disk drives, firms that developed smaller form factors had to simultaneously develop new tools and manufacturing processes to make them (King and Tucci, 2002). However, there may be other process innovation-specific reasons that innovation might proceed in a countercyclical fashion. The first is that the lower demand may trigger a search for lower cost of producing the product, i.e. a cost-saving process innovation, which would give the firm immediate cost relief. Thus, process innovation could positively influence firms' profitability in a downturn, assuming the existence of low-hanging-fruit opportunities, process innovations that involve cost-saving and productivity-enhancing activities could allow firms to reap profits, despite the lower demand (Pisano, 1997). The second is a forward-thinking approach in which the firm anticipates the end of the downturn. Productivity-improving activities could provide firms with cost advantages when demand recovers (Saint-Paul, 1993). The aforementioned arguments imply:

$\mathrm{H} 2 \mathrm{a}$ : there is a positive relationship between an industry downturn and firms' propensity to engage in process innovation.

\subsubsection{Pro-cyclical process innovation investment}

Finally, as depicted in the lower right quadrant of Table 1, there could be several reasons why process innovation investments may be pro-cyclical, beyond the correlation with product innovation investments as described earlier in the text. First, owing to a lack of slack financial resources, firms may decide not to engage in process innovation to improve a current set of products whose values are depreciated or depreciating (Yang et al., 2004). In this case, process innovation could have a low return on investment owing to the low demand of existing products. In some sense, it is similar to the logic of "throwing bad money after good" if demand does not recover; then, investments in process innovation will have been for naught. Moreover, when demand expands again later on, completely new market areas could be more attractive, making existing products obsolete. Therefore, any investment to enhance the productivity of current products could run the risk of being lost, as these products may not meet future demand. These arguments would leave one to conclude:

$\mathrm{H} 2 \mathrm{~b}$ : there is a negative relationship between an industry downturn and firms' propensity to engage in process innovation. 


\section{Method}

The data for this study on innovation activities in the manufacturing sector come from the SIMFs run by the Research Department of Capitalia Banking Group. ${ }^{1}$ The goal of the surveys was to analyze the structure and the evolution of the Italian manufacturing firms focusing primarily on innovation activities, imports and exports, and financial structure and needs. The first survey was conducted on a random sample of firms in 1992 (covering the period 1989-1991), the second survey in 1995 (covering 1992-1994), the third survey in 1998 (covering 1995-1997), the fourth survey in 2001 (covering 1998-2000), and the latest one in 2004 (covering the period 2001-2003). ${ }^{2}$ For reasons of consistency of questions asked in the survey, in this study, we focus on the 1998, 2001, and 2004 surveys. $^{3}$

The questionnaire and methodology for the survey related to the innovation and technology section is similar to that adopted for the Community Innovation Survey. In the questionnaire, firms are asked whether they innovate based on definitions of innovation that involve product innovation, process innovation, organizational/operational innovations related to products, and organizational/operational innovations related to processes.

The SIMF is an unbalanced data set, as a small number of firms did not continue to provide information from one 3-year "wave" to the next for several reasons (mergers, changes to non-manufacturing activity, non-response [e.g. too busy] or ceasing production). New companies were included in the Survey each wave in an attempt to maintain representativeness. After eliminating a small number of observations owing to inconsistencies in the data, we have a panel with 622 firms that are present for at least two consecutive waves, for a total of 1795 observations for the period 1995-2003 (93\% of firms are present in every wave). ${ }^{4}$ Using this data set, we are able to use panel data techniques and carry out analysis of dynamic models. To date, few studies have undertaken such an analysis in the innovation literature, probably owing to the lack of availability of times series data in many countries.

We also use data from ISTAT (Italian National Institute of Statistics), a public research organization and the main producer of official statistics since 1926. We were able to retrieve information about industrial production from each industry manufacturing sector as well as on imports and exports. Next, we use data from

\footnotetext{
${ }^{1}$ On October 1, 2007, Capitalia was acquired and merged into Unicredit Group, one of the largest banks in the world. As of November 16, 2012, Unicredit is ranked 154th in the Global 500 (Source: Fortune).

${ }^{2}$ This latest survey expanded industry coverage to include services, construction, and electricity as well.

${ }^{3}$ The SIMF is being used by an increasing number of scholars (e.g. Hall et al., 2008; Berchicci, 2011; Berchicci, 2013).

${ }^{4}$ Excluding those firms that are not in every wave does not change the results reported later in the text.
} 
"Movimprese," a database managed by Infocamere, the Association of the Italian Chamber of Commerce. This data set reports the total number of firms in each industry each year. Furthermore, the estimates of the concentration index are based on revenue (turnover) figures for each firm obtained from the AIDA database 5 and are referenced to the year 2003. Table 2 illustrates the industries present in the panel, their Herfindal-Hirschmann Index, the number of firms in each industry and their propensity to innovate.

During the 1995-2003 period, 64\% of firms surveyed engaged in innovation activities, whether product or process innovation. The rate of product innovation was $\sim 14 \%$, whereas that of process innovation was circa $25 \%$ (the rate of those who performed both product and process innovation was $\sim 25 \%$ ). These firms represent 19 "industries" (at the two-digit level of the ATECO 1991 classification system) ${ }^{6}$ in the manufacturing sector. The majority of the firms come from the industries "Machinery and Equipment," "Fabricated Metal Products, Except Machinery and Equipment," "Food Products and Beverages," and "Textiles," which together account for almost $50 \%$ of the entire sample (Table 2).

Table 3 displays a description of the variables used in the study, together with summary descriptive statistics. We also have dummy variables for each wave of the surveys, (not reported in Table 3). Later in the text, we provide detailed information on these variables.

\section{Measures}

\subsection{Dependent variables}

In the SIMF questionnaire, firms are asked about their innovation activities and output. They needed to indicate whether they engaged in new or significantly improved product or process innovations and any organizational/operational innovations related to these innovations. ${ }^{7}$ Based on these questions, we constructed four dependent variables_ "innovation," "broad product innovation," "focused product innovation" and "focused process innovation." The former is equal to 1 if the firm developed any type of innovation, whether product or process innovation, zero

\footnotetext{
${ }^{5}$ This is a product by Bureau Van Dijk that contains financial information (in the form of company accounts, ratios, activities, ownership, subsidiaries, and management) on 280,000 Italian companies.

6 The Italian version of the North-American Industry Classification System (NAICS) or the European Nomenclature Statistique des activités économiques dans la Communauté européenne (NACE) classification.

7 The actual questions were (translated from Italian): "Within the last 36 months, has your firm introduced any product innovations?," "Within the last 36 months, has your firm introduced any process innovations?," and so forth. Thus, the respondent himself or herself selects the appropriate response(s).
} 


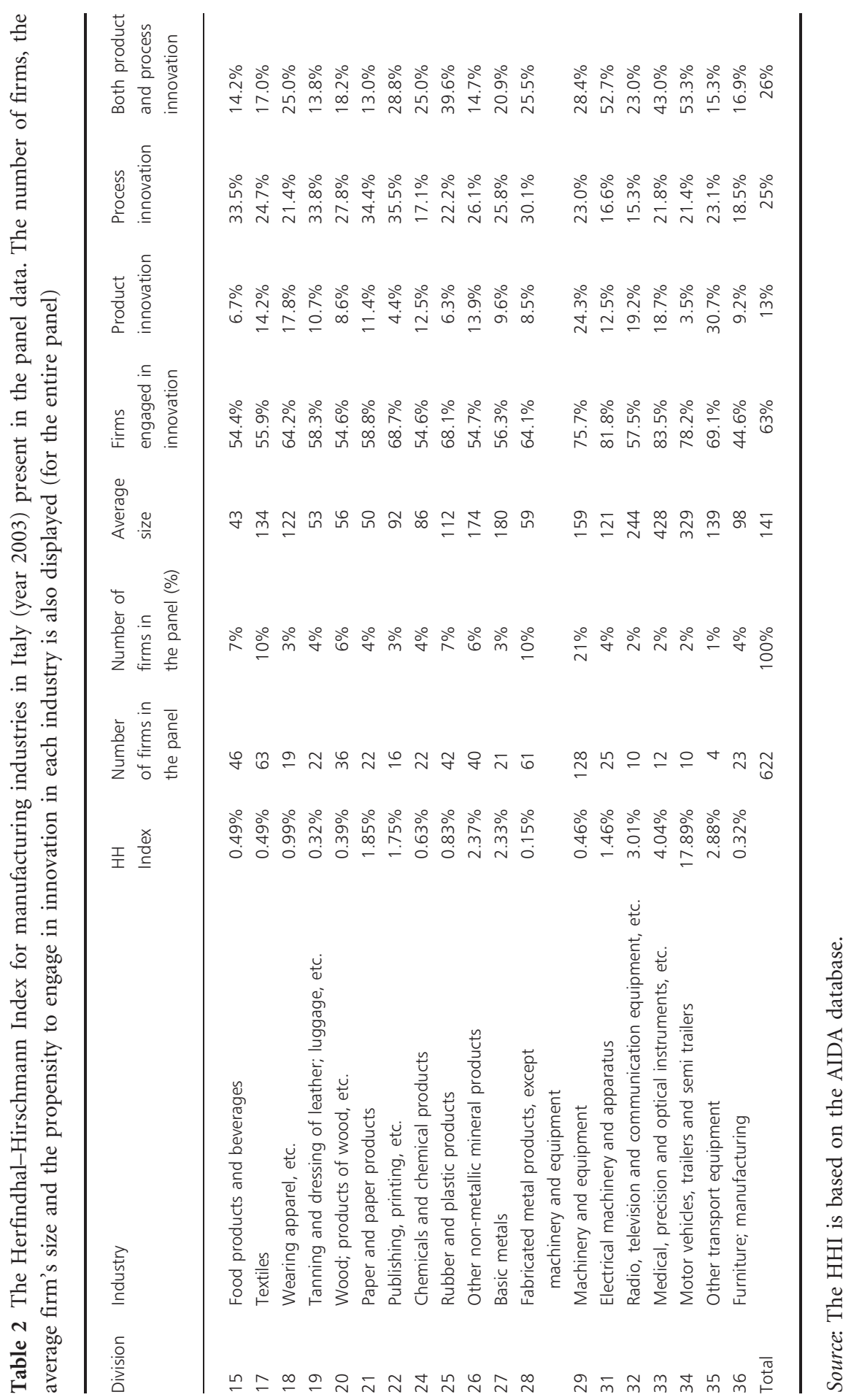




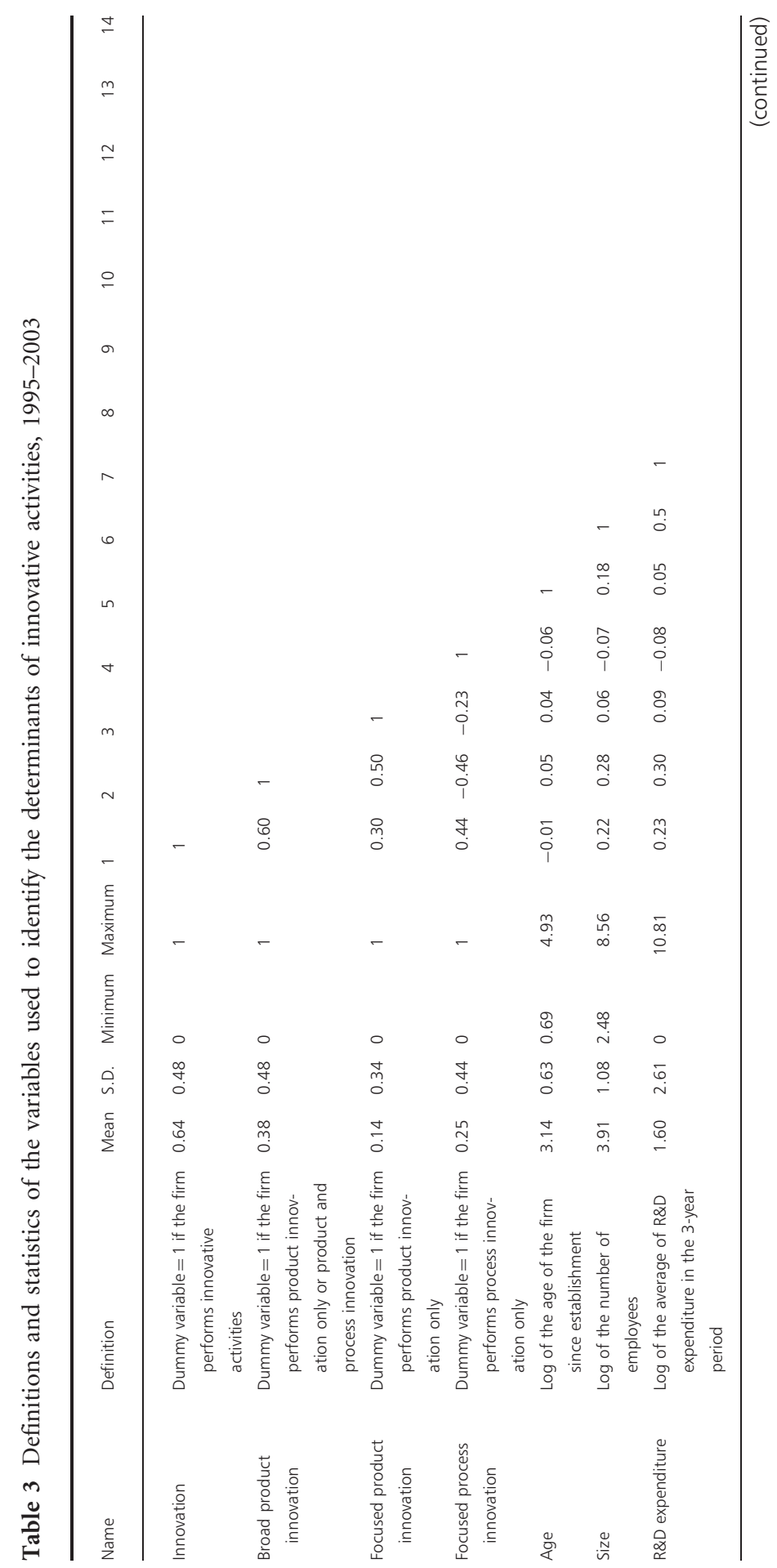




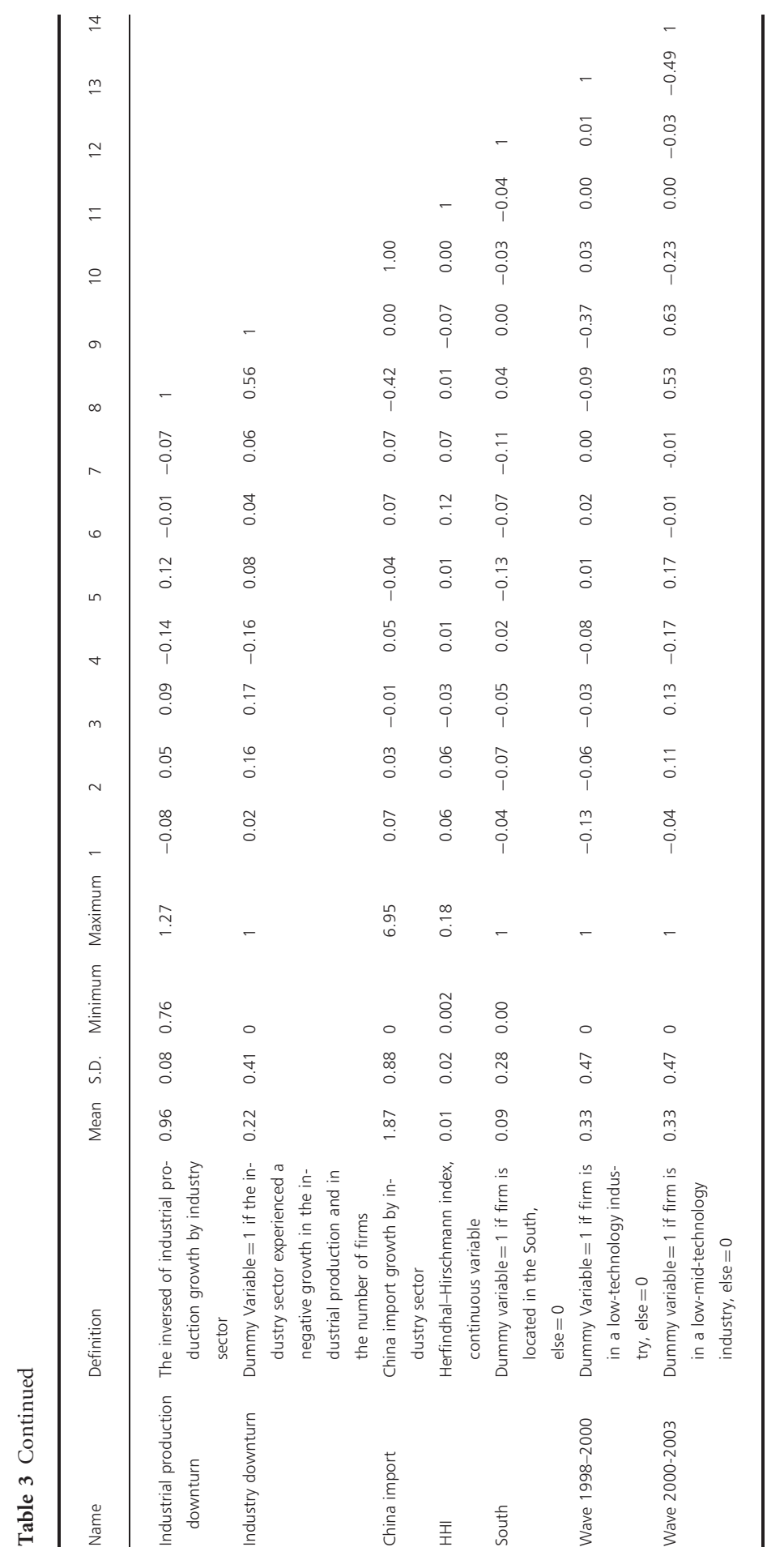


otherwise. This variable is used in our basic model in our analysis. For the types of innovation, we use three definitions. The first one includes those firms that develop product innovation only and product innovation that required innovation in the process as well. Owing to complementarities between these activities these two types of innovation are often mutually supportive (Milgrom and Roberts, 1995; Pisano, 1997). This variable includes those firms that develop a process innovation to develop new products. Broad product innovation takes a value equal to 1 if the firm developed a product innovation or organizational/operational innovation related to product innovation or developed product and process innovation simultaneously, zero otherwise. Focused product innovation is equal to 1 for firms that performed product innovation only (or organizational/operational innovation related to product innovation only). Focused process innovation equals 1 if the firm engaged in process innovation only (or organizational/operational innovation related to process innovation only).

\subsection{Independent variable}

To measure industry fluctuations and specifically industry downturns, we use industrial production data. Industrial production offers a convenient way to proxy demand (both domestic and global, as $73 \%$ of the firms in the sample export), as industrial production changes are sensitive to changes in consumer and supply demand (Gehman and Motheral, 1968). Industrial production is a measure of change in output for industrial sectors in the economy. We retrieved industrial production data for each of the industry categories in our sample (at the two digit level). Table 4 shows the growth rate of industrial production per industry sector over the sample period. The industrial production downturn variable is the inverse growth rate of industrial production for each three-year survey period. For example, to calculate the growth rate in 1995-1997, we took the average of industrial production of a given industry between 1995 and 1997 and divided by the average of industrial production of the same industry between 1992 and 1994. We then calculated the inverse growth rate to capture downturn. Next to this variable, we provide an additional and a more conservative measure of industry downturns. We do so by combining the industrial production downturn with the number of firms in a given industry. When both industrial production and number of firms decline in a given period, we would expect a stronger effect of this combined industry downturn measure on a firm's propensity to engage in product or process innovation. To test this hypothesis empirically, we first create a dummy variable that captures whether there is a decline in the number of firms in a given period based on Table 4 that shows these changes in percentage terms. For example, for the 2004 survey covering the years 2001-2003, we consider the number of active firms at the beginning of 2001 and at the end of 2003. If the growth rate is negative, the sector is considered to experience a "downturn," otherwise it is considered an "upturn." Next, we create the 


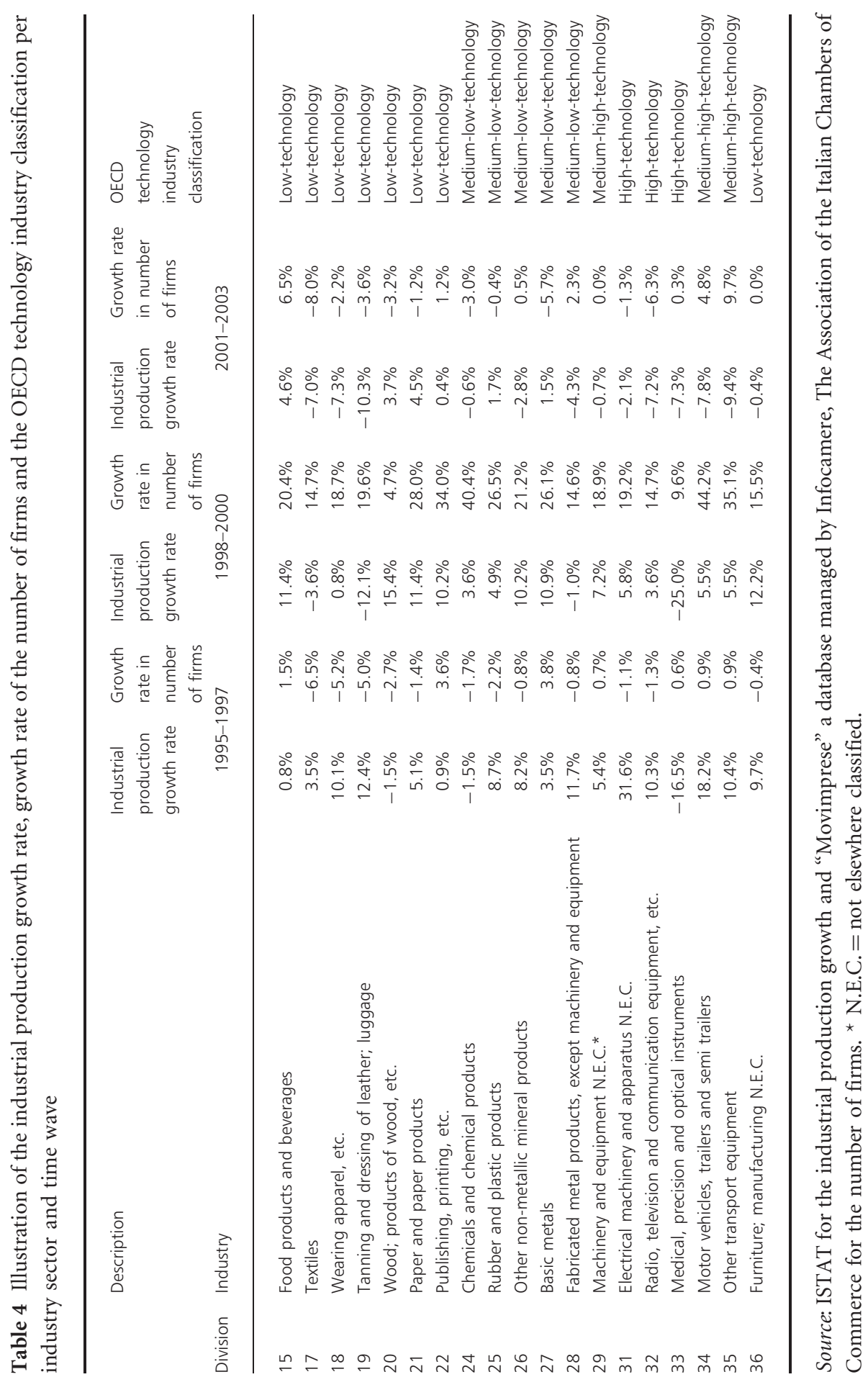


"industry downturn dummy" variable. It is equal to 1 when both industrial production and number of firms declined in a given period and for a given industry.

\subsection{Control variables}

For control variables, we take into account firm characteristics, as well as other environmental factors that may influence the firm's innovation activities. We control for firm characteristics, mainly the age and the size of the firm, and R\&D expenditures. The age of the firm is equal to the log of the number of years since the date of establishment. The size of the firm is expressed by the log of the number of employees in a given year. We control for investments in Research and Development activities as well. R\&D expenditure is the average of R\&D expenditures in the 3-year period covered by a given survey. We take its logarithmic form. We also include region-level characteristics. South, a dummy variable equal to 1 if the firm is located in the Southern regions of Italy. According to the SIMF classification, we select firms located in the following regions: Abruzzo, Basilicata, Calabria, Campania, Molise, Puglia, Sardinia, and Sicily. As most Italian manufacturing firms are located in the Northern part of Italy, this variable takes into account regional differences, which has been found to be important for innovation activities (Roper et al., 2000; Sternberg and Arndt, 2001).

We include three industry factors. First, $H H I$ is represents the value of the Herfindhal-Hirschmann Index (the scale adopted for the Index is from 0.0 to 1.0 , where a 1.0 is obtained in the case of a monopoly). For each industry, we first calculated the market share of each firm as the ratio between the firm's sales (turnover) and total industry sales, and then we estimated the Herfindhal-Hirschmann Index:

$$
\mathrm{HHI}=\sum_{i=1}^{N} s_{i}^{2}
$$

where $s_{i}$ is the market share of firm $i$ and $N$ is the number of firms. Thus, HHI is the sum of the squared market share of each firm in the industry at issue (see Table 2). The HHI is influenced by the relative market share of each firm in the industry (the higher the market share of one firm, the more concentrated the industry) and by the number of firms in the industry (the higher the number of competitors in a particular industry, the less concentrated the industry).

Second, we include China import that captures the change in imported goods from China across our time per industry sector. This variable attempts to control for increasing competition in manufacturing from Chinese companies. Stronger competition from China could force Italian firms to withdraw from process innovation while focusing on activities for new product introductions. ${ }^{8}$ Third, each model includes dummy variables for every industry sector at the two-digit level.

\footnotetext{
${ }^{8}$ We would like to thank one of our anonymous reviewers for suggesting this idea.
} 


\section{Analytical procedures}

We follow the conventional practice of using a discrete and limited dependent variable model $^{9}$ to analyze the determinants of innovation. The probability to innovate is modeled as:

$$
y_{i t}=\mathrm{X}_{\mathrm{it}} \beta^{\prime}+\mu_{i t}
$$

where:

$$
y_{i t}=\left\{\begin{array}{l}
1 \text { if } y_{i t}>0 \text { i.e. firm innovates in a given period } \mathrm{t} \\
0 \text { otherwise }
\end{array}\right.
$$

and $\mathrm{X}_{\mathrm{it}}$ is the set of exogenous (independent) explanatory variables and $\mu_{i t}$ the error term.

The probability of innovation is modeled as a probit model.

We develop our analysis building a model for each definition of innovation, where the independent variables are chosen according to existing studies at a similar level of analysis:

$$
\text { INNOVATION }=\mathrm{f}(\text { Firm, Industry, Region, Other Controls })
$$

$$
\begin{aligned}
& \text { BROAD PRODUCT INNOVATION }= \\
& \mathrm{f}(\text { Firm, Industry, Region, Other Controls })
\end{aligned}
$$

$$
\begin{aligned}
& \text { FOCUSED PRODUCT INNOVATION }= \\
& \mathrm{f}(\text { Firm, Industry, Region, Other Controls })
\end{aligned}
$$

$$
\begin{aligned}
& \text { FOCUSED PROCESS INNOVATION }= \\
& \qquad \mathrm{f}(\text { Firm, Industry, Region, Other Controls })
\end{aligned}
$$

where INNOVATION is the probability of a firm innovating; BROAD PRODUCT INNOVATION is the probability of a firm innovating in products or in products and processes simultaneously. FOCUSED PRODUCT INNOVATION is the probability of a firm innovating in products only; FOCUSED PROCESS INNOVATION is the probability of a firm innovating in process only. The econometric treatment takes into account (i) that the dependent variable is binary and (ii) that we have

\footnotetext{
${ }^{9}$ For an excellent review of regression models for categorical and limited dependent variables, see Long (1997).
} 
panel data. Thus we use "random effects" probit models to control for unobserved heterogeneity. ${ }^{10}$

\section{Results}

Table 5 reports the results of the random effects estimations. In Model 1, our dependent variable is "innovation." We find that ReD and size are positively associated with innovation activities. These findings suggest that firms that perform R\&D and large ones have a stronger tendency to engage in innovation activities (than non$\mathrm{R} \& \mathrm{D}$-performers and smaller firms, respectively). We do not find that firm age and regional characteristics (South) nor China import influences the propensity to innovate. Turning to our variable of interest, we observe that there is no apparent relationship between industrial production downturns and firms' innovation activities.

The dependent variable in Model 2 is broad product innovation, whereas in Model 3 , it is focused product innovation. The effect of our main independent variable is similar in both models. We find that a period of decline in industrial production does influence the firm's propensity to engage in broad product innovation (at $10 \%$ statistical significance) and focused product innovation (at 1\%). On the contrary, Model 4 shows that, under the same industry conditions, firms engage in less process innovation (at 5\%). These results suggest a negative association between industrial production downturns and process innovation. Models 5-8 show the effect of the more conservative independent variable, industry downturn dummy, on the firm's propensity to engage in overall innovation activities, product innovation, and process innovation. The results are similar to those shown in models $1-4$, although the overall effects are stronger. These models demonstrate that in such downturns firms tend to develop more product innovations and produce fewer process innovations. In economic terms, the probability to engage in broad product innovation and focused product innovation in downturns increases by $17 \%$ and $11 \%$, respectively, and decreases by $12 \%$ in process innovation. This seems to suggest that when both the number of firms and industrial production decline in a given period/industry their combined effect on firms' innovation activities is stronger. Overall, firms developing new processes require brighter economic prospects to extract results. An industry downturn may trigger firms in that industry to find new product opportunities. These results are consistent with both Hypotheses $1 \mathrm{a}$ and $2 \mathrm{~b}$. They confirm $\mathrm{H} 1 \mathrm{a}$ because we find that there is a positive relationship between greater downturns and firms' propensity for product innovation. They confirm H2b by suggesting that downturns are negatively associated with firms' propensity for process innovation.

\footnotetext{
${ }^{10}$ We also used other specifications, including a conditional logit model with firm fixed effects, which found similar results but with a greatly reduced number of observations owing to the lack of variables changing values during the course of the panel (see Appendix Table A1).
} 


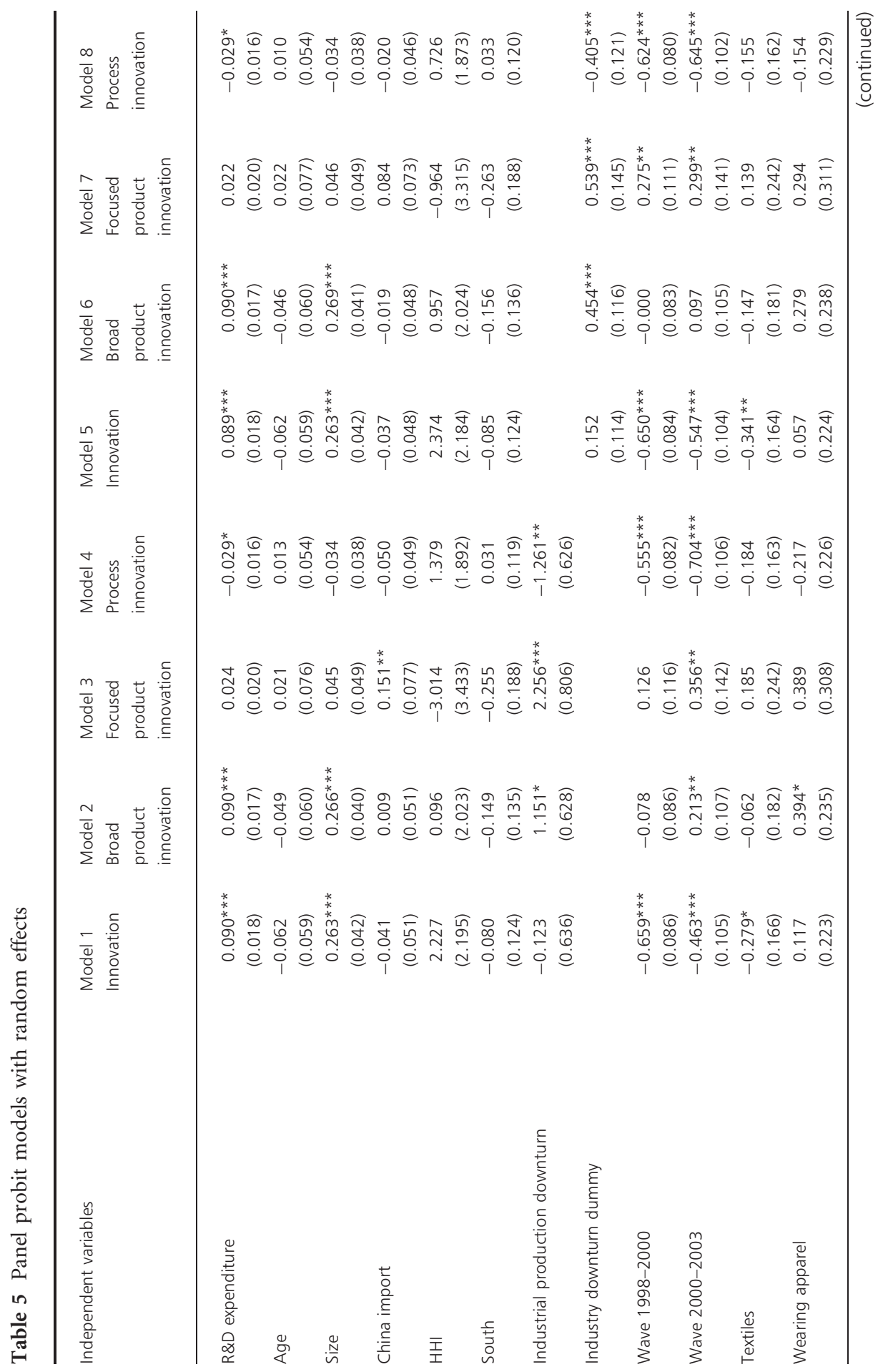




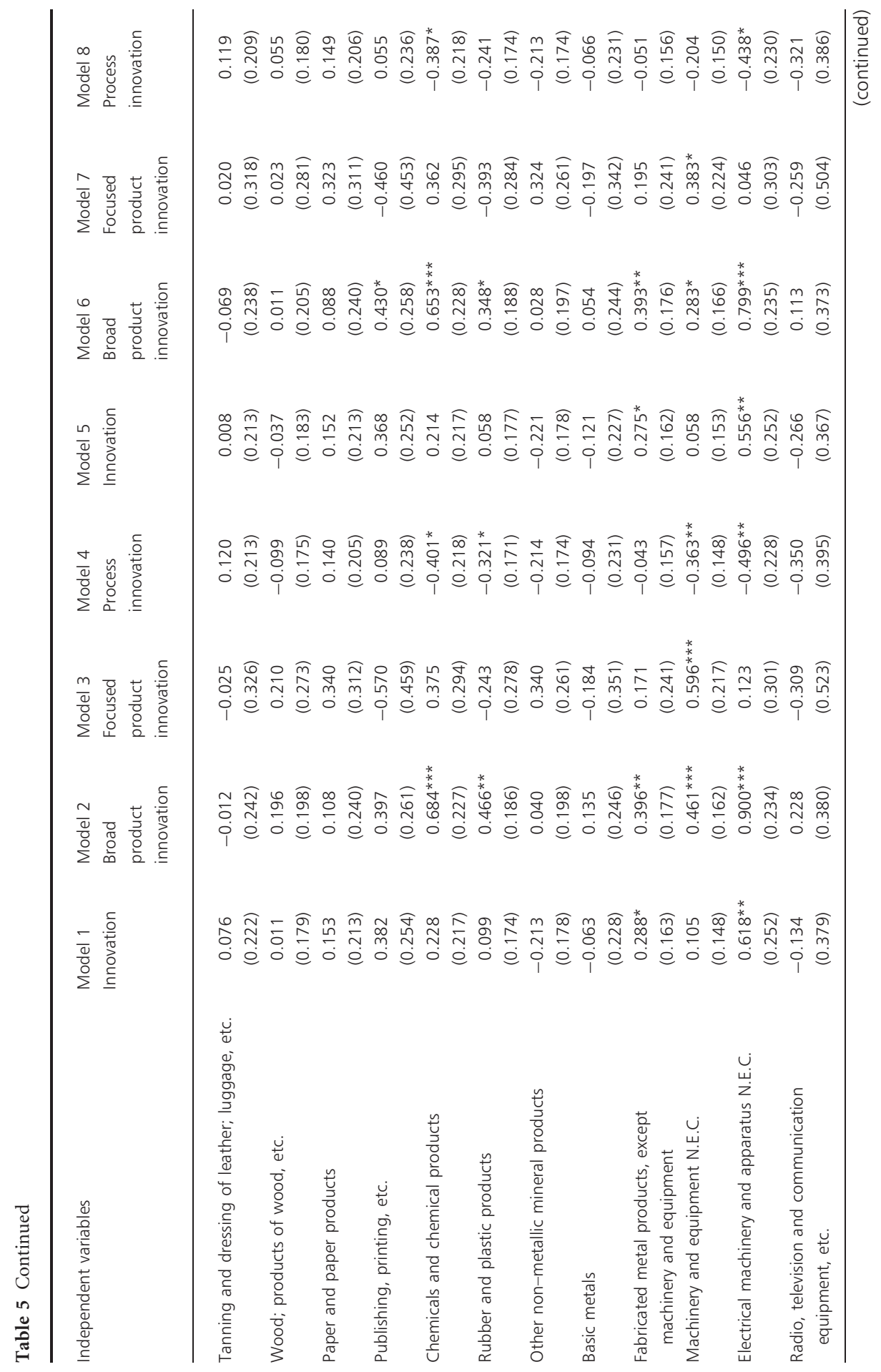




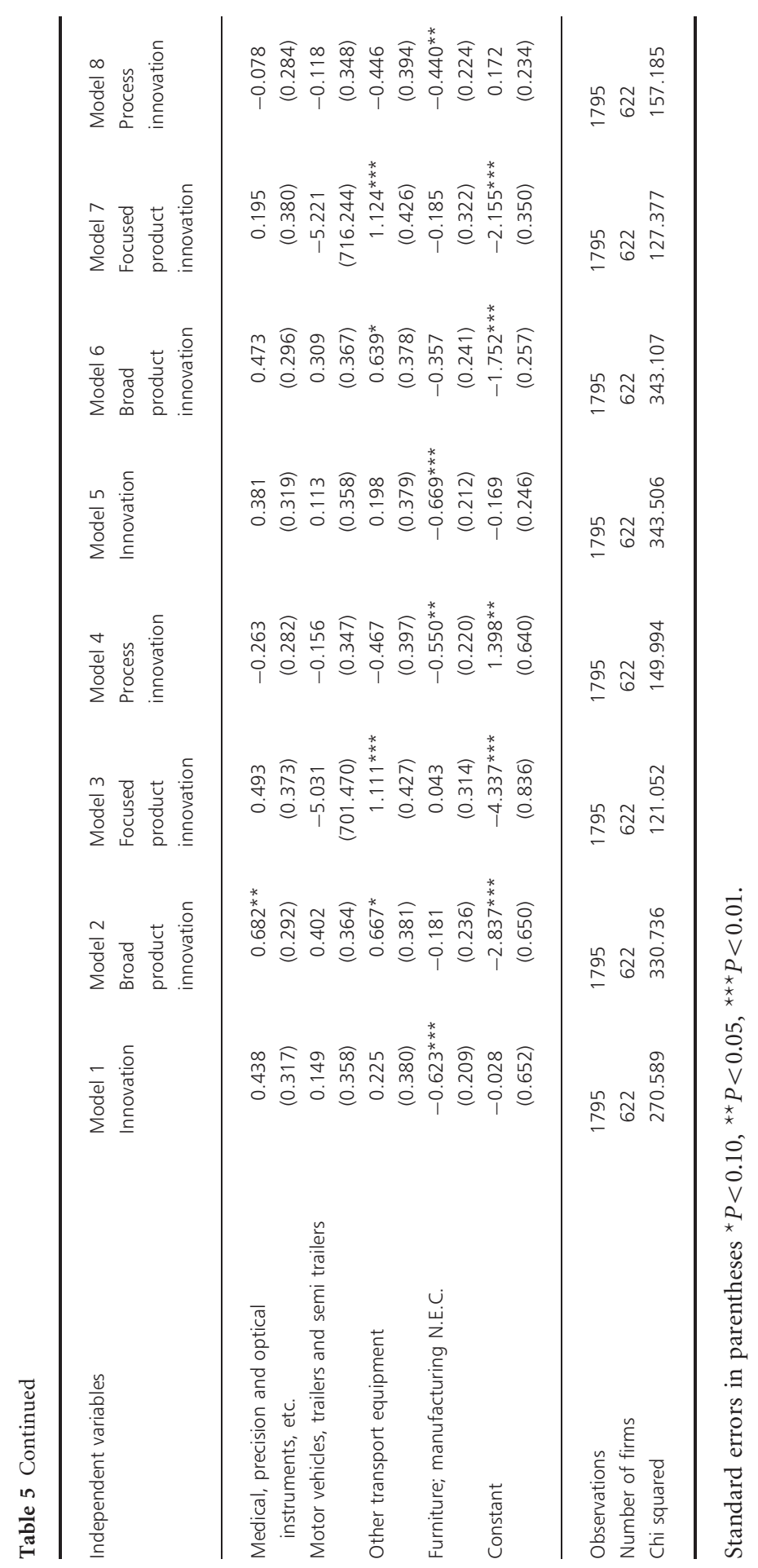


Furthermore, these findings seem to suggest that the significant and opposite effects of a period of decline on product and process innovation are concealed and become insignificant when product and process innovation are grouped together.

Turning to the control variables, we find that China import has a positive and statistically significant association with product innovation (but no association with process innovation). This effect could suggest that greater Chinese competition drove Italian companies to focus their efforts in new product development activities, or finding themselves often as suppliers, Chinese companies deliver goods to sustain new product development of Italian firms.

\subsection{Robustness checks}

To test whether our results were robust, we ran several additional tests. In Hypothesis 1a, our argument for counter-cyclical behavior is based on the notion that firms in downturns would invest in product innovation by creating new products rather than improving existing ones. For our empirical analysis, however, we used a question from the surveys that refers to product innovation in general terms. One may argue that such a variable does not clearly distinguish between new products and incremental improvements to existing products. The lack of such distinction in our data set may pose serious concerns for hypothesis testing. To address this issue, we make use of another question present in the surveys that deals with investment goals. The respondent is asked to select the investment goals out of seven items and, if it applies, to indicate the degree of importance of specific investment goals on a three-point Likert scale ("low," "medium," and "high" importance). The interesting feature of this query is that it clearly distinguishes investment goals in new products from investment goals in product-enhancing features. We infer that if firms gave high priority to "really new" product investments during downturns, they are more likely to come up with "really new" product innovations. Thus, we used this measure to provide a more conservative test for Hla. First, we selected the two items that refer to product innovation: (i) investments for improving the quality of existing products and (ii) investments to develop new products. ${ }^{11}$ Second, we used these two items as two dependent variables whose values range from 1 (low importance) to 3 (high importance). Third, given the variable characteristics, we used an ordered probit method (and clustered the standard error around the firm id) to test whether downturns affect investments in really new products and in incremental products. Table 6 shows the results. Models 1 and 3 contain really new product investment as the dependent variable, whereas Models 2 and 4 include incremental product investment as the dependent variable. The number of observations is reduced substantially, especially in Models 1 and 3, as only half of the respondents answered that question.

\footnotetext{
${ }^{11}$ The other five items refer to investments (i) to increase production of existing products, (ii) to lower environmental impact (of production), (iii) to cut material input, and (iv) to cut labor.
} 
Table 6 Ordered probit models with "really-new" product investment and incremental product investment as dependent variables

\begin{tabular}{|c|c|c|c|c|}
\hline Independent variables & $\begin{array}{l}\text { Model } 1 \\
\text { Really new } \\
\text { product } \\
\text { investment }\end{array}$ & $\begin{array}{l}\text { Model } 2 \\
\text { Incremental } \\
\text { product } \\
\text { investment }\end{array}$ & $\begin{array}{l}\text { Model } 3 \\
\text { Really new } \\
\text { product } \\
\text { investment }\end{array}$ & $\begin{array}{l}\text { Model } 4 \\
\text { Incremental } \\
\text { product } \\
\text { investment }\end{array}$ \\
\hline$R \& D$ & $\begin{array}{l}0.057^{* * *} \\
(0.019)\end{array}$ & $\begin{array}{r}-0.017 \\
(0.015)\end{array}$ & $\begin{array}{l}0.055^{* * *} \\
(0.019)\end{array}$ & $\begin{array}{r}-0.017 \\
(0.015)\end{array}$ \\
\hline Age & $\begin{array}{c}-0.085 \\
(0.074)\end{array}$ & $\begin{array}{c}0.050 \\
(0.054)\end{array}$ & $\begin{array}{c}-0.076 \\
(0.074)\end{array}$ & $\begin{array}{c}0.050 \\
(0.054)\end{array}$ \\
\hline Size & $\begin{array}{l}0.170^{* * *} \\
(0.047)\end{array}$ & $\begin{array}{l}0.092 * * \\
(0.040)\end{array}$ & $\begin{array}{l}0.171^{* * *} \\
(0.047)\end{array}$ & $\begin{array}{l}0.092^{* *} \\
(0.040)\end{array}$ \\
\hline China import & $\begin{array}{c}0.080 \\
(0.069)\end{array}$ & $\begin{array}{c}0.064 \\
(0.040)\end{array}$ & $\begin{array}{c}0.022 \\
(0.065)\end{array}$ & $\begin{array}{c}0.047 \\
(0.038)\end{array}$ \\
\hline $\mathrm{HHI}$ & $\begin{array}{c}1.775 \\
(1.542)\end{array}$ & $\begin{array}{c}1.376 \\
(1.659)\end{array}$ & $\begin{array}{c}3.254^{* *} \\
(1.567)\end{array}$ & $\begin{array}{c}1.555 \\
(1.670)\end{array}$ \\
\hline South & $\begin{array}{r}-0.035 \\
(0.186)\end{array}$ & $\begin{array}{c}0.152 \\
(0.120)\end{array}$ & $\begin{array}{c}-0.029 \\
(0.184)\end{array}$ & $\begin{array}{c}0.156 \\
(0.120)\end{array}$ \\
\hline Industrial production downturn & & & $\begin{array}{l}0.425^{* * *} \\
(0.118)\end{array}$ & $\begin{array}{c}0.052 \\
(0.112)\end{array}$ \\
\hline Industry downturn dummy & $\begin{array}{l}2.173^{* * *} \\
(0.818)\end{array}$ & $\begin{array}{c}0.635 \\
(0.586)\end{array}$ & & \\
\hline Wave 1998-2000 & $\begin{array}{c}0.051 \\
(0.113)\end{array}$ & $\begin{array}{c}0.021 \\
(0.074)\end{array}$ & $\begin{array}{c}0.173 \\
(0.110)\end{array}$ & $\begin{array}{c}0.044 \\
(0.071)\end{array}$ \\
\hline Wave 2000-2003 & $\begin{array}{c}-0.477^{* * *} \\
(0.141)\end{array}$ & $\begin{array}{r}-0.131 \\
(0.100)\end{array}$ & $\begin{array}{c}-0.465^{* * *} \\
(0.123)\end{array}$ & $\begin{array}{r}-0.095 \\
(0.099)\end{array}$ \\
\hline Textiles & $\begin{array}{c}-0.283 \\
(0.220)\end{array}$ & $\begin{array}{r}-0.029 \\
(0.167)\end{array}$ & $\begin{array}{r}-0.328 \\
(0.219)\end{array}$ & $\begin{array}{r}-0.001 \\
(0.163)\end{array}$ \\
\hline Wearing apparel & $\begin{array}{c}0.109 \\
(0.321)\end{array}$ & $\begin{array}{c}0.034 \\
(0.204)\end{array}$ & $\begin{array}{c}0.028 \\
(0.322)\end{array}$ & $\begin{array}{c}0.045 \\
(0.206)\end{array}$ \\
\hline Tanning and dressing of leather; luggage, etc. & $\begin{array}{c}0.060 \\
(0.388)\end{array}$ & $\begin{array}{c}0.109 \\
(0.218)\end{array}$ & $\begin{array}{c}0.081 \\
(0.393)\end{array}$ & $\begin{array}{c}0.145 \\
(0.209)\end{array}$ \\
\hline Wood; products of wood, etc. & $\begin{array}{c}0.048 \\
(0.239)\end{array}$ & $\begin{array}{r}-0.165 \\
(0.163)\end{array}$ & $\begin{array}{r}-0.056 \\
(0.246)\end{array}$ & $\begin{array}{r}-0.184 \\
(0.169)\end{array}$ \\
\hline Paper and paper products & $\begin{array}{c}0.174 \\
(0.234)\end{array}$ & $\begin{array}{r}-0.076 \\
(0.227)\end{array}$ & $\begin{array}{c}0.132 \\
(0.237)\end{array}$ & $\begin{array}{r}-0.079 \\
(0.227)\end{array}$ \\
\hline Publishing, printing, etc. & $\begin{array}{c}0.257 \\
(0.271)\end{array}$ & $\begin{array}{r}-0.339 \\
(0.210)\end{array}$ & $\begin{array}{c}0.349 \\
(0.276)\end{array}$ & $\begin{array}{r}-0.309 \\
(0.207)\end{array}$ \\
\hline Chemicals and chemical products & $\begin{array}{c}0.408^{*} \\
(0.239)\end{array}$ & $\begin{array}{c}0.181 \\
(0.202)\end{array}$ & $\begin{array}{c}0.384 \\
(0.240)\end{array}$ & $\begin{array}{c}0.184 \\
(0.203)\end{array}$ \\
\hline Rubber and plastic products & $\begin{array}{c}0.191 \\
(0.207)\end{array}$ & $\begin{array}{r}-0.162 \\
(0.163)\end{array}$ & $\begin{array}{c}0.070 \\
(0.211)\end{array}$ & $\begin{array}{r}-0.170 \\
(0.164)\end{array}$ \\
\hline Other non-metallic mineral products & $\begin{array}{r}-0.018 \\
(0.233)\end{array}$ & $\begin{array}{r}-0.150 \\
(0.180)\end{array}$ & $\begin{array}{r}-0.008 \\
(0.234)\end{array}$ & $\begin{array}{r}-0.146 \\
(0.180)\end{array}$ \\
\hline Basic metals & $\begin{array}{r}-0.269 \\
(0.258)\end{array}$ & $\begin{array}{r}-0.283 \\
(0.233)\end{array}$ & $\begin{array}{r}-0.306 \\
(0.262)\end{array}$ & $\begin{array}{r}-0.255 \\
(0.230)\end{array}$ \\
\hline $\begin{array}{l}\text { Fabricated metal products, except machinery and } \\
\text { equipment }\end{array}$ & $\begin{array}{l}0.410^{* *} \\
(0.205)\end{array}$ & $\begin{array}{r}-0.043 \\
(0.162)\end{array}$ & $\begin{array}{l}0.455^{* *} \\
(0.205)\end{array}$ & $\begin{array}{r}-0.029 \\
(0.161)\end{array}$ \\
\hline
\end{tabular}


Table 6 Continued

\begin{tabular}{|c|c|c|c|c|}
\hline Independent variables & $\begin{array}{l}\text { Model } 1 \\
\text { Really new } \\
\text { product } \\
\text { investment }\end{array}$ & $\begin{array}{l}\text { Model } 2 \\
\text { Incremental } \\
\text { product } \\
\text { investment }\end{array}$ & $\begin{array}{l}\text { Model } 3 \\
\text { Really new } \\
\text { product } \\
\text { investment }\end{array}$ & $\begin{array}{l}\text { Model } 4 \\
\text { Incremental } \\
\text { product } \\
\text { investment }\end{array}$ \\
\hline Machinery and equipment N.E.C. & $\begin{array}{c}0.301 \\
(0.183)\end{array}$ & $\begin{array}{c}0.150 \\
(0.140)\end{array}$ & $\begin{array}{c}0.117 \\
(0.191)\end{array}$ & $\begin{array}{c}0.121 \\
(0.144)\end{array}$ \\
\hline Electrical machinery and apparatus N.E.C. & $\begin{array}{l}0.523^{* *} \\
(0.240)\end{array}$ & $\begin{array}{r}-0.066 \\
(0.184)\end{array}$ & $\begin{array}{c}0.474^{*} \\
(0.243)\end{array}$ & $\begin{array}{r}-0.048 \\
(0.185)\end{array}$ \\
\hline Radio, television and communication equipment, etc. & $\begin{array}{c}0.235 \\
(0.432)\end{array}$ & $\begin{array}{r}-0.156 \\
(0.306)\end{array}$ & $\begin{array}{c}0.260 \\
(0.399)\end{array}$ & $\begin{array}{r}-0.082 \\
(0.305)\end{array}$ \\
\hline Medical, precision and optical instruments, etc. & $\begin{array}{c}0.232 \\
(0.352)\end{array}$ & $\begin{array}{c}0.197 \\
(0.340)\end{array}$ & $\begin{array}{r}-0.012 \\
(0.364)\end{array}$ & $\begin{array}{c}0.160 \\
(0.344)\end{array}$ \\
\hline Motor vehicles, trailers and semi trailers & $\begin{array}{c}0.490 \\
(0.393)\end{array}$ & $\begin{array}{l}0.618^{* *} \\
(0.306)\end{array}$ & $\begin{array}{c}0.455 \\
(0.390)\end{array}$ & $\begin{array}{l}0.625^{* *} \\
(0.305)\end{array}$ \\
\hline Other transport equipment & $\begin{array}{c}1.094^{*} \\
(0.643)\end{array}$ & $\begin{array}{r}-0.302 \\
(0.381)\end{array}$ & $\begin{array}{c}1.115^{*} \\
(0.672)\end{array}$ & $\begin{array}{c}-0.277 \\
(0.384)\end{array}$ \\
\hline Furniture; manufacturing N.E.C. & $\begin{array}{c}0.477 \\
(0.298)\end{array}$ & $\begin{array}{c}0.154 \\
(0.233)\end{array}$ & $\begin{array}{c}0.256 \\
(0.304)\end{array}$ & $\begin{array}{c}0.134 \\
(0.234)\end{array}$ \\
\hline Constant (cut1) & $\begin{array}{l}2.306^{* * *} \\
(0.809)\end{array}$ & $\begin{array}{r}-0.404 \\
(0.583)\end{array}$ & $\begin{array}{c}0.227 \\
(0.322)\end{array}$ & $\begin{array}{c}-1.010^{* * *} \\
(0.244)\end{array}$ \\
\hline Constant (cut2) & $\begin{array}{l}3.234^{* * *} \\
(0.814)\end{array}$ & $\begin{array}{c}0.839 \\
(0.586)\end{array}$ & $\begin{array}{l}1.159^{* * *} \\
(0.324)\end{array}$ & $\begin{array}{c}0.232 \\
(0.242)\end{array}$ \\
\hline Observations & 898 & 1515 & 898 & 1515 \\
\hline Chi squared & 171.46 & 43.13 & 178.29 & 42.43 \\
\hline
\end{tabular}

Standard errors in parentheses ${ }^{\star} P<0.10,{ }^{* *} P<0.05,{ }^{* * *} P<0.01$.

The findings suggest that firms tend to give high importance to investments in really new products during downturns. On the contrary, we do not find a significant effect of downturns on incremental product investments. Overall, these results provide robust evidence consistent with Hypothesis 1a.

As an additional robustness check, we also used a specification including the type of industry-in relative terms, low-tech, medium-low-tech, medium-high-tech, and high-tech industries - rather than two-digit industry dummies as illustrated in Table 4. These are four different dummy variables, each capturing industry technological effort according to the Organization for Economic Cooperation and Development (OECD) technology industry classification (Hatzichronoglou, 1997). As previous research suggests (e.g. Cainelli et al. 2001; Mohnen and Dagenais, 2002; Nascia and Perani, 2002), industry type could strongly influence firms' innovation activities. The default case relative to the other three is "low-tech." In the appendix, Table A2 shows that firms in low-tech industries are less likely to engage in 
innovation activities during downturns. Overall, our results are confirmed. Third, we include a financial variable named financial risk that captures the 1-year probability of default from the RiskCalc Italy model developed by Moody's $\operatorname{KMV}^{12}(2002,2005)$. This variable allows us to better understand the pro-cyclical argument by determining whether firms might not invest in innovation activities owing to environmental uncertainty versus owing to cash constraints or poor financial conditions. Table A3 in the appendix shows that financial risk has no effect on the likelihood of engaging in innovation and product innovation activities, whereas it has a rather weak influence on process innovation. Although the number of observations declines to 1,596 (and 598 firms), Table A3 presents consistent results. Overall, these findings suggest that firms' creditworthiness has little explanatory power. Fourth, we run simultaneous logistic regressions to check whether the standard errors of the different estimations were correlated. Specifically, we used unrelated bivariate probit regressions with robust standard errors (the biprobit command in Stata). Although it controls for robust standard errors, its application is suboptimal, as it does not handle panel data. Finally, we run our models including only those firms that are present in every wave. With 1,653 observations (and 551 firms), we find similar findings (see Table A4 in the appendix).

\section{Discussion and Conclusion}

We examine the role of an important aspect of the economic environment on firms' innovation processes. By distinguishing product from process innovation, we see that industry fluctuations have differential associations with each of these two types. In the case of industry downturns, firms tend to engage in product innovation rather than in process innovation. Our results have implications for both theory and research design.

From a theoretical perspective, our findings provide a contribution by bridging opportunity cost theory with the cash flow effect. The results clearly indicate how firms allocate their resources for innovation activities in an industry downturn-they realize new products rather new processes. Why? An explanation is likely to be derived by integrating these two previously incompatible arguments (see Figure 1).

During an industry downturn, the revenues of current products may drop along with the value of existing products. Given that, firms may need to strategically reallocate their limited resources. They may decide to restructure their relatively less profitable product activities by reallocating resources to develop new innovative and

12 RiskCalc Italy, first released in October 2002 and regularly revised to take into account all evolution in the financial and regulatory environment, is the first Basel 2-compliant rating model based on publicly available data to assess private firms' creditworthiness and constitutes a benchmark in the Italian financial industry. Balance sheet data used to calculate the 1-year probability of default are obtained from the AIDA database and refer to years 1996 and 1997 (first survey), 1999 and 2000 (second survey), 2002 and 2003 (third survey). 


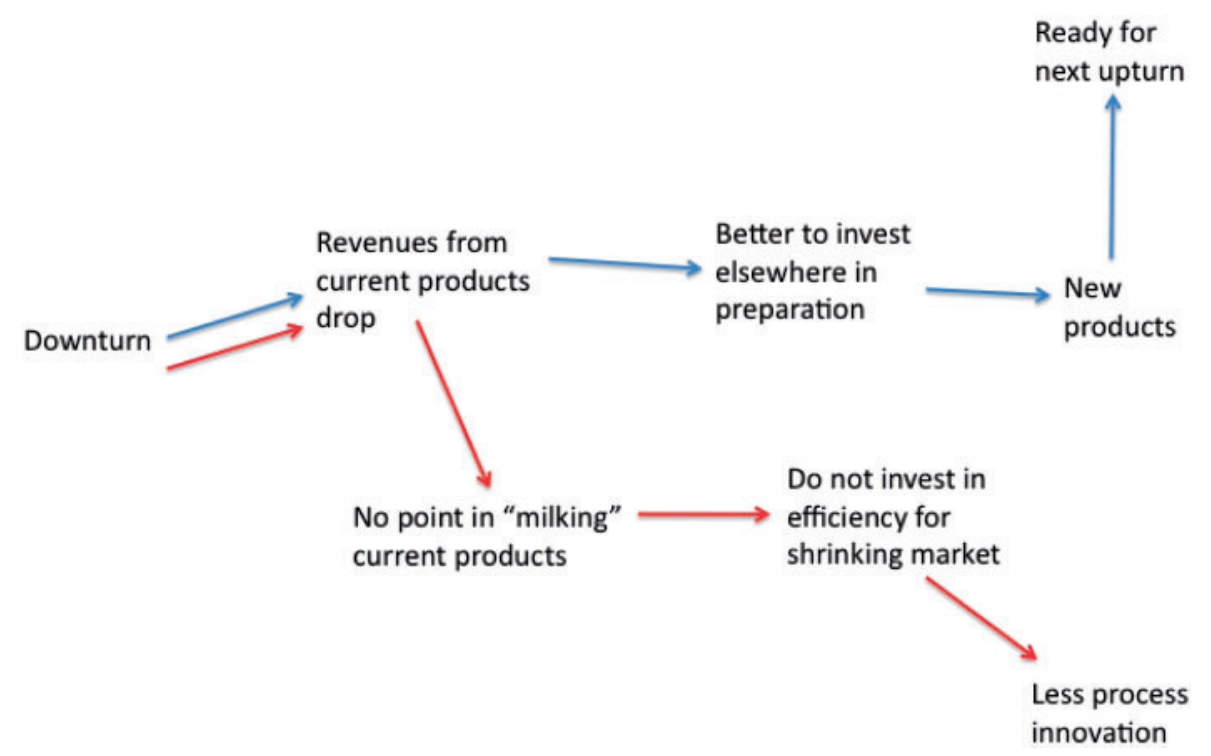

Figure 1 Logic behind different innovation investment decisions in downturns.

potentially profitable products. The alternative option-engaging in process innovation-is less likely, as it may not be profitable in the long-term to increase the efficiency of producing existing products whose value may be plummeting. Therefore, firms seem to have incentives to engage only in product innovation (where process innovation is complementary to new products) as the loss of diminishing rents from current products is larger than the relative return to be secured by implementing new products (Arrow, 1962; Geroski, 1995; Saint-Paul, 1997). As a consequence, they may invest fewer resources in process innovation for depreciating products because the window of improving productivity for those products is rather small. On the contrary, by realizing new products, firms prepare themselves for the next upturn, which could provide the market with potential rent-generating product innovations. Overall, we contribute to the literature on the effect of downturns on a firm's propensity to innovate by clearly showing how some innovation activities may be counter-cyclical and others pro-cyclical. The time horizon over which firms are able to profit from these activities is likely to influence the division between the two. During industry downturns, by engaging in product innovation, firms will benefit in the longer-term when the next expansion takes place. On the other hand, engaging in process innovation is likely to be a pro-cyclical activity as firms will benefit from such innovation in the shorter-term by improving existing products in times of high demand.

At first glance, it appears that our results are inconsistent with Nickell et al.'s (2001) work, where UK manufacturing firms seem to invest in managerial 
innovation oriented toward productivity improvements during negative business cycles. However, the way Nickell and co-authors measured this construct makes it difficult to compare directly with what we have studied. Nickell et al. focused on human resource practices, changes in industrial relations, and a perceived change in how "lean" the company became (which may or may not reflect lean manufacturing practices). Theoretically, all of these practices could be pursued simultaneously with product innovation.

From a research design point of view, separating product and process innovation adds insight over lumping them together in an all-encompassing innovation measure. As mentioned in the Section 1, previous empirical studies have shown conflicting results regarding the influence of industry fluctuations cycles on firms' innovation activities. Despite the different empirical methods and samples used, our results may provide us with an explanation for these previously conflicting results. When we combine product and process innovation together under the denomination of innovation activities, the effects of the determinants of interest are not significant. On the other hand, when we make a clear distinction between product and process innovation, we find that downturns are positively associated with product innovation and negatively with process innovation. Overall, these findings suggest that without a clear separation between product and process innovation, the effects of environmental factors could lead to blurred or biased results. When product and process innovation are concealed to the eye of the researcher, the relative weight of one type of innovation over the other one will define the significance and the direction of the relationship. For example, in a particular sample or industry when firms pursue relatively more process or product innovations, but a proxy that combines the two types is used, the results of any analysis will reflect the relatively higher weight of one type vis-à-vis the other. For example, by investigating how recessions influence a firm's R\&D expenditure, Saint Paul (1993) finds that such an effect is "sometimes positive, sometimes negative, and always very insignificant" (p.880). Such conflicting findings could be due to the fact that R\&D expenditure often encompasses investments in both productivity-enhancing activities for existing products and the development of new products. By separating them, we argue, the results may have a different flavor.

The empirical separation of innovation activities into product and process innovation suggests that other factors could have an influence on firms' propensity to engage in innovation activities. For example, in Table A2, we find a negative relationship between product innovation and market concentration. This result is consistent with prior scholars who predict investments in product innovation to survive under competitive pressure (Porter, 1980, 1986; Weiss, 2003). Competition may increase innovation because firms have incentives to increase their technological lead over rivals in a "neck-and-neck" technology race (Aghion et al., 1998). Future research may explore different types of industries and how they react differently to industry fluctuations. 
We point out the findings from this study are by no means definitive. Further investigations are required before broad prescriptions related to these findings can be made. First, the industry sector classification at the two-digit level may be not optimal to cluster firms. A more detailed level of analysis may provide a better aggregate measure and lead to more conservative results. Second, the variables built on the SIMF data may suffer from the typical "subjectivity" weakness of any survey, such as reporting and fulfilment biases. Third, the sample is a comprehensive one, covering all areas of manufacturing activity in Italy. Inasmuch as Italian market structure may be idiosyncratic (e.g. a larger number of smaller firms than other OECD countries), the results may be less generalizable, although it is one of the largest economies in the world and one of the most developed, it is not obvious how a bias toward small firms should influence the results. If anything, one would expect less process innovation from smaller firms, which would make the results reported here more conservative. In addition, findings from this article break new ground by providing large-sample empirical evidence on the environmental and market structure determinants of product and process innovation. Finally, our explanation for the underlying logic of realizing product versus process innovation was based on "matching" the patterns observed with the theories developed at the beginning of this article. This matching might well be modified as we learn more about these investments in future research.

Taken together, the findings provide some explanation for conflicting results of previous research where there was no distinction made between product and product innovation. By comparing two different perspectives, our results also provide an overarching theoretical explanation of firms' propensity to innovate in industry downturns. Finally, using finer-grained measures enables us to contribute to the important debate on the role of the economic environment on the innovation processes of firms.

\section{Acknowledgements}

The authors thank the Editor, Fredrik Tell, and the four anonymous referees. They also benefitted from comments by Iftekhar Hasan and Shu Han, DRUID 2012 discussants Andrea Mina and Andrea Fosfuri, participants at the DRUID conference in 2012, and participants at the International Tor Vergata Conference on Money, Banking and Finance in 2011.

\section{References}

Abernathy, W. J. and J. M. Utterback (1978), 'Patterns of industrial innovation,' Technology Review, 80(7), 40-47.

Aghion, P., P. Howitt, M. Brant-Collett and C. García-Peñalosa (1998), Endogenous growth theory. MIT Press: Cambridge, Massachusetts. 
Anderson, P. and M. L. Tushman (1990), 'Technological discontinuities and dominant designs-a cyclical model of technological-change,' Administrative Science Quarterly, 35(4), 604-633.

Ansoff, H. I. (1958), 'A model for diversification,' Management Science, 4(4), 392-414.

Arrow, K. J. (1962), 'Economic welfare and the allocation of resources for innovations,' in R. Nelson (ed.), The Rate and Direction of Incentive Activity: Economic and Social Factors. Princeton University Press: Princeton, NJ.

Berchicci, L. (2013), 'Towards an open R\&D system: internal R\&D investment, external knowledge acquisition and innovative performance,' Research Policy, 42(1), 117-127.

Berchicci, L. (2011), 'Heterogeneity and intensity of R\&D partnership in Italian manufacturing firms,' IEEE Transactions on Engineering Management, 58(4), 674-687.

Cainelli, G., N. De Liso, R. Monducci and G. Perani (2001), 'Technological innovation and firm performance in Italian traditional manufacturing sectors,' in Eurostat (ed.), Innovation and Enterprise Creation: Statistics and Indicators: Sophia Antipolis, Nice.

Damanpour, F. (1991), 'Organizational innovation-a metaanalysis of effects of determinants and moderators,' Academy of Management Journal, 34(3), 555-590.

Dixit, A. K. and R. S. Pindyck (1994), Investment under uncertainty. Princeton University Press: Princeton, NJ.

Drucker, P. F. (1985), Innovation and entrepreneurship: practice and principles. 1st edn. Harper \& Row: New York.

Garcia, R. and R. Calantone (2002), 'A critical look at technological innovation typology and innovativeness terminology: a literature review,' Journal of Product Innovation Management, 19(2), 110-132.

Gehman, C. and C. Motheral (1968), 'Measures of industrial production and final demand,' in J. W. Kendrick (ed.), The Industrial Composition of Income and Product. Columbia University Press: New York.

Geroski, P. A. (1995), 'What do we know about entry?' International Journal of Industrial Organization, 13(4), 421-440.

Geroski, P. A. and C. F. Walters (1995), 'Innovative activity over the business-cycle,' Economic Journal, 105(431), 916-928.

Gort, M. and S. Klepper (1982), 'Time paths in the diffusion of product innovations,' The Economic Journal, 92(367), 630-653.

Hall, B. H., F. Lotti and J. Mairesse (2008), 'Employment, innovation, and productivity: evidence from Italian microdata,' Industrial and Corporate Change, 17(4), 813-839.

Hall, H. R. (1991a), 'Labor demand, labor supply, and employment volatility', NBER Macroeconomics Annual, 6, 17-47.

Hall, R. E. (1991b), Recessions as reorganizations. NBER Macroeconomics Annual: Cambridge, MA.

Hatzichronoglou, T. (1997), 'Revision of the high-technology sector and product classification,' STI Working Papers, 1997/2. OECD: Paris. 
Himmelberg, C. P. and B. C. Petersen (1994), 'R \& D and internal finance: a panel study of small firms in high-tech industries,' The Review of Economics and Statistics, 76(1), 38-51.

Jovanovic, B. and G. M. MacDonald (1994), 'The life cycle of a competitive industry,' The Journal of Political Economy, 102(2), 322-347.

King, A. A. and C. L. Tucci (2002), 'Incumbent entry into new market niches: the role of experience and managerial choice in the creation of dynamic capabilities,' Management Science, 48(2), 171-186.

Kleinknecht, A. (1984), 'Prosperity, crisis and innovation patterns,' Cambridge Journal of Economics, 8(3), 251-270.

Klepper, S. (1997), 'Industry life cycles,' Industrial and Corporate Change, 6(1), 145-182.

Kurkkio, M., J. Frishammar and U. Lichtenthaler (2011), 'Where process development begins: a multiple case study of front end activities in process firms,' Technovation, 31(9), 490-504.

Long, J. S. (1997), Regression models for categorical and limited dependent variables. Sage Publications: Thousand Oaks.

McGahan, A. M. and M. E. Porter (1999), 'The persistence of shocks to profitability,' Review of Economics and Statistics, 81(1), 143-153.

McGahan, A. M. and B. S. Silverman (2001), 'How does innovative activity change as industries mature?' International Journal of Industrial Organization, 19(7), 1141-1160.

Milgrom, P. and J. Roberts (1995), 'Complementarities and fit-strategy, structure, and organizational-change in manufacturing,' Journal of Accounting \& Economics, 19(2-3), 179-208.

Mitchell, W. (1989), 'Whether and when-probability and timing of incumbents entry into emerging industrial subfields,' Administrative Science Quarterly, 34(2), 208-230.

Mohnen, P. and M. Dagenais (2002), 'Towards an innovation intensity index: the case of CIS 1 in Denmark and Ireland,' in A. Kleinknecht and P. Mohnen (eds), Innovation and Firm Performance: Econometric Explorations of Survey Data. Palgrave: New York.

Nascia, L. and G. Perani (2002), 'Diversity of innovation in europe,' International Review of Applied Economics, 16(3), 277-293.

Nickell, S., D. Nicolitsas and M. Patterson (2001), 'Does doing badly encourage management innovation?' Oxford Bulletin of Economics and Statistics, 63(1), 5-28.

Penrose, E. T. (1959), The theory of the growth in the firm. Basil Blackwell: Oxford, England.

Pisano, G. P. (1990), 'The research-and-development boundaries of the firm-an empiricalanalysis,' Administrative Science Quarterly, 35(1), 153-176.

Pisano, G. P. (1991), 'The governance of innovation-vertical integration and collaborative arrangements in the biotechnology industry,' Research Policy, 20(3), 237-249.

Pisano, G. P. (1997), The development factory: unlocking the potential of process innovation. Harvard Business School Press: Boston.

Porter, M. E. (1980), Competitive strategy: techniques for analyzing industries and competitors. Free Press: New York. 
Porter, M. E. (1986), Competition in global industries. Harvard Business School Press: Boston, Massachusetts.

Rafferty, M. (2003), 'Do business cycles alter the composition of research and development expenditures?' Contemporary Economic Policy, 21(3), 394-405.

Reichstein, T. and A. Salter (2006), 'Investigating the sources of process innovation among UK manufacturing firms,' Industrial and Corporate Change, 15(4), 653-682.

Roper, S., J. H. Love, B. Ashcroft and S. Dunlop (2000), 'Industry and location effects on UK plants' innovation propensity,' Annals of Regional Science, 34(4), 489-502.

Saint-Paul, G. (1993), 'Productivity growth and the structure of the business cycle,' European Economic Review, 37(4), 861-883.

Saint-Paul, G. (1997), 'Business cycles and long-run growth,' Oxford Review Economic Policy, 13(3), 145-153.

Scherer, F. M. (1982), 'Demand-pull and technological invention: schmookler revisted,' The Journal of Industrial Economics, 30(3), 225-237.

Schmookler, J. (1966), Invention and economic growth. Harvard University Press: Cambridge.

Schon, D. A. (1967), Technology and change; the new Heraclitus. Delacorte Press: New York.

Schumpeter, J. A. (1934), The theory of economic development. Harvard University Press: Cambridge, Massachusetts.

Shleifer, A. (1986), 'Implementation cycles,' The Journal of Political Economy, 94(6), $1163-1190$.

Sternberg, R. and O. Arndt (2001), 'The firm or the region: what determines the innovation behavior of European firms?’ Economic Geography, 77(4), 364-382.

Suarez, F. F. and J.M. Utterback (1995), 'Dominant designs and the survival of firms,' Strategic Management Journal, 16(6), 415-430.

Weiss, P. (2003), 'Adoption of product and process innovations in differentiated markets: the impact of competition,' Review of Industrial Organization, 23(3-4), 301-314.

Windrum, P. (2005), 'Heterogeneous preferences and new innovation cycles in mature industries: the amateur camera industry 1955-1974,' Industrial and Corporate Change, 14(6), 1043-1074.

Yang, B., N. D. Burns and C. J. Backhouse (2004), Management of uncertainty through postponement. Taylor \&amp; Francis: Abingdon, ROYAUME-UNI. 


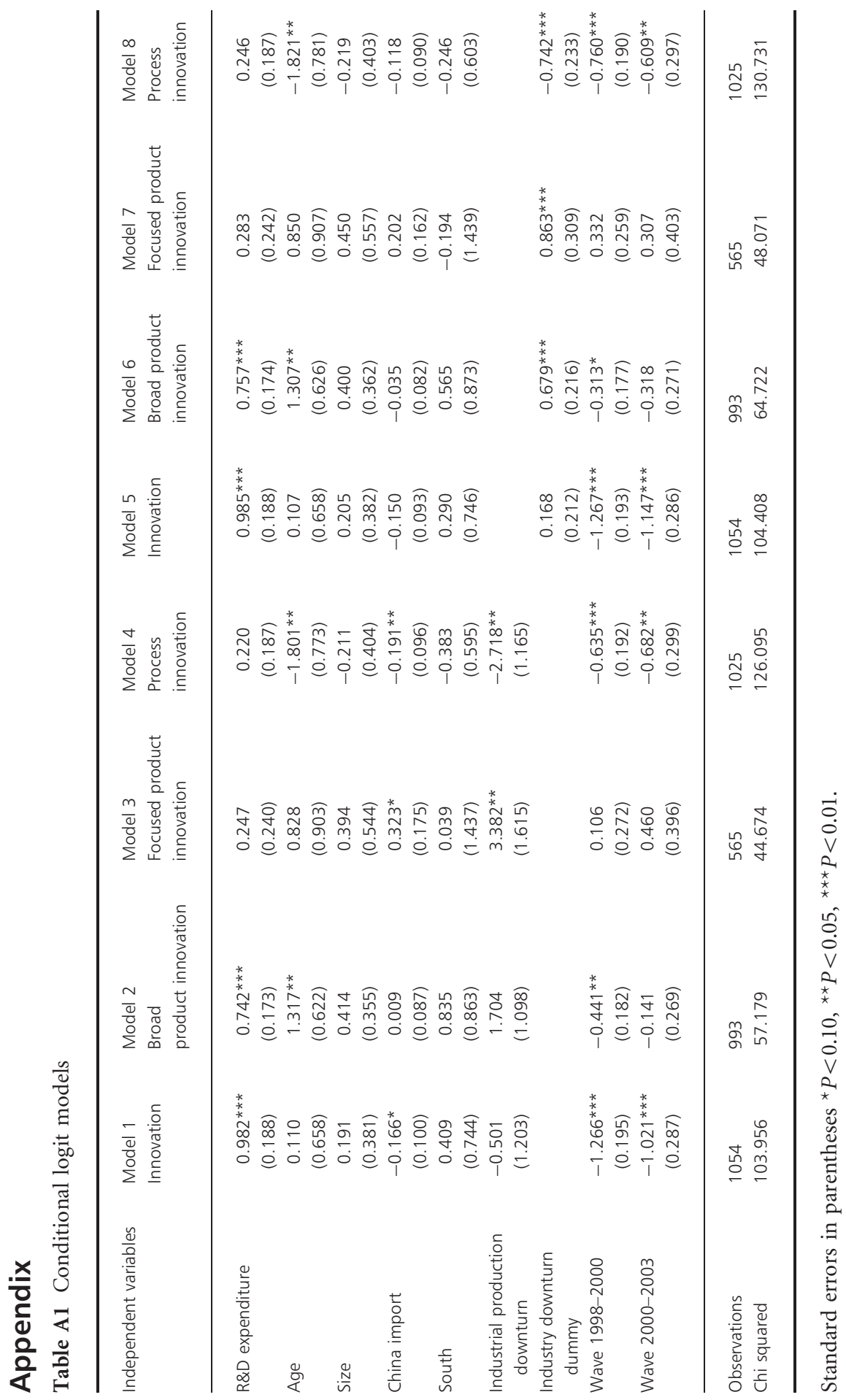




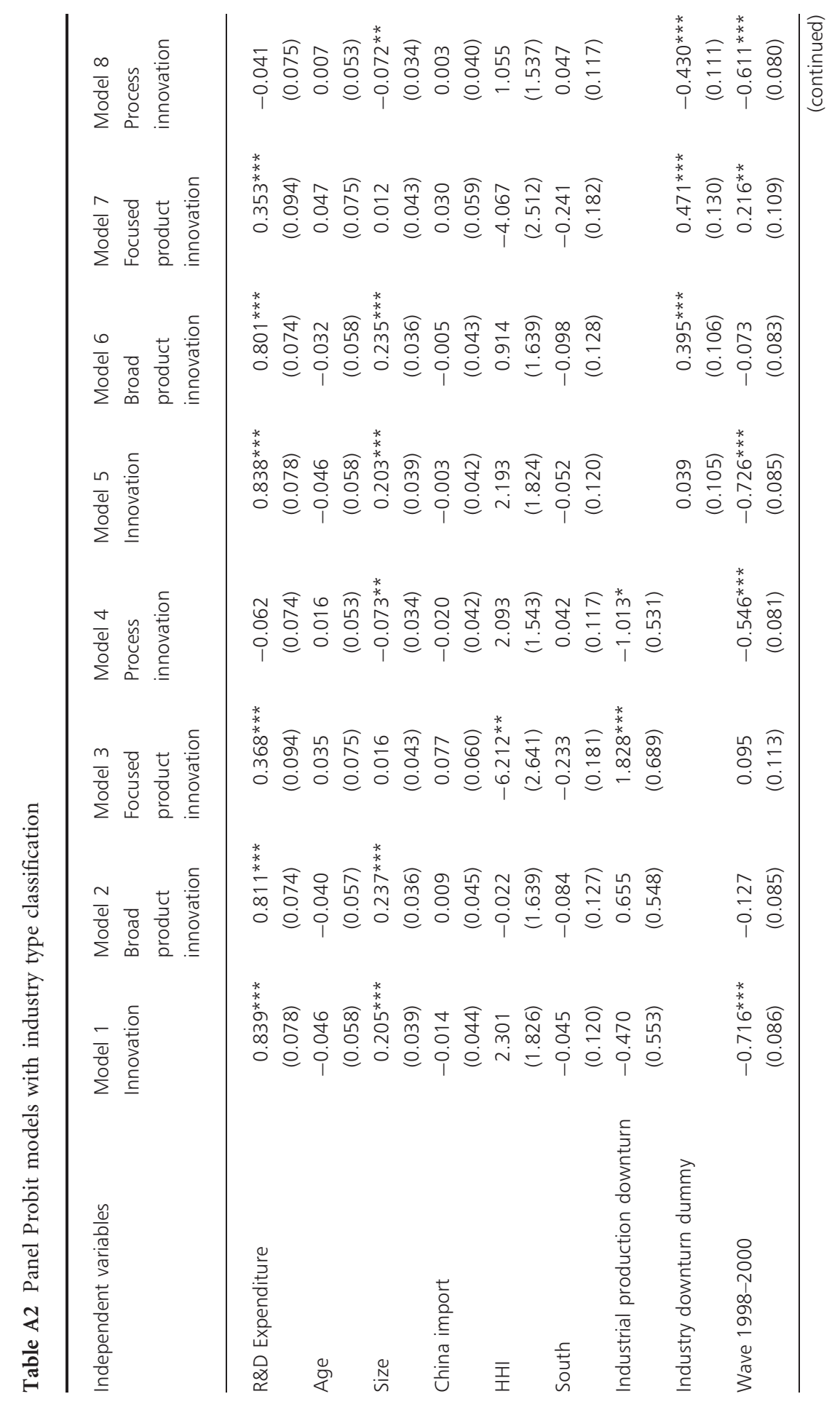




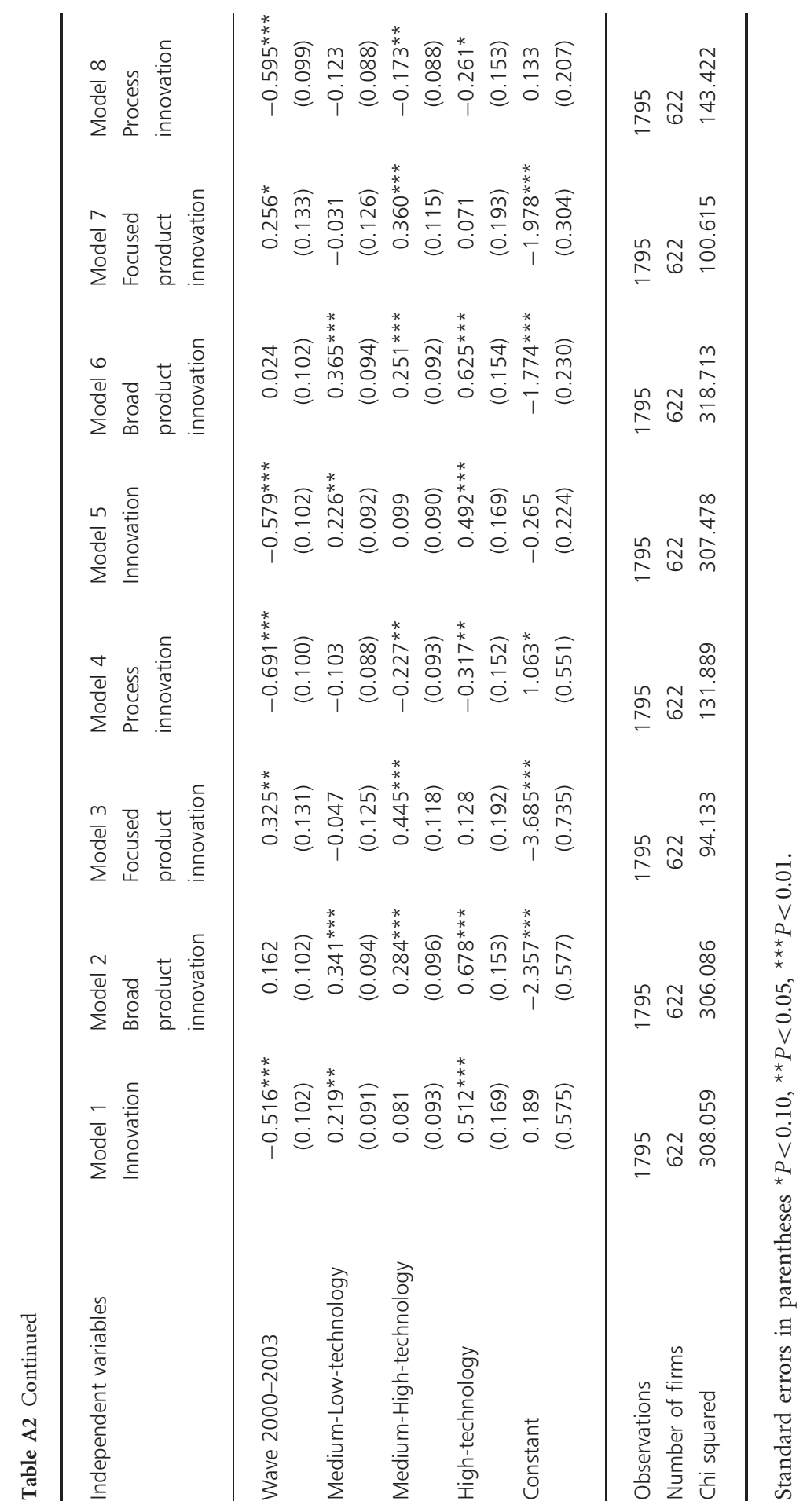




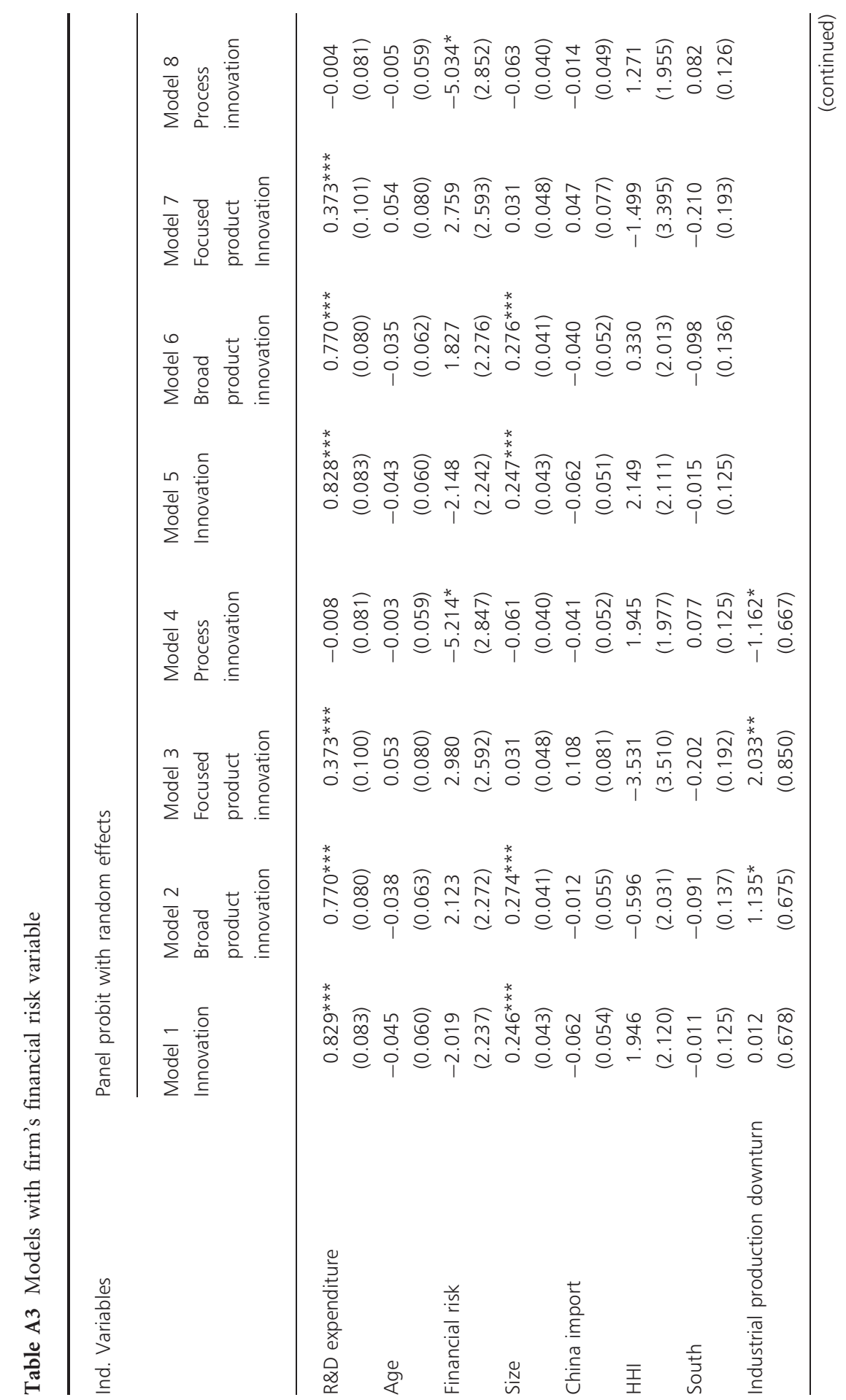




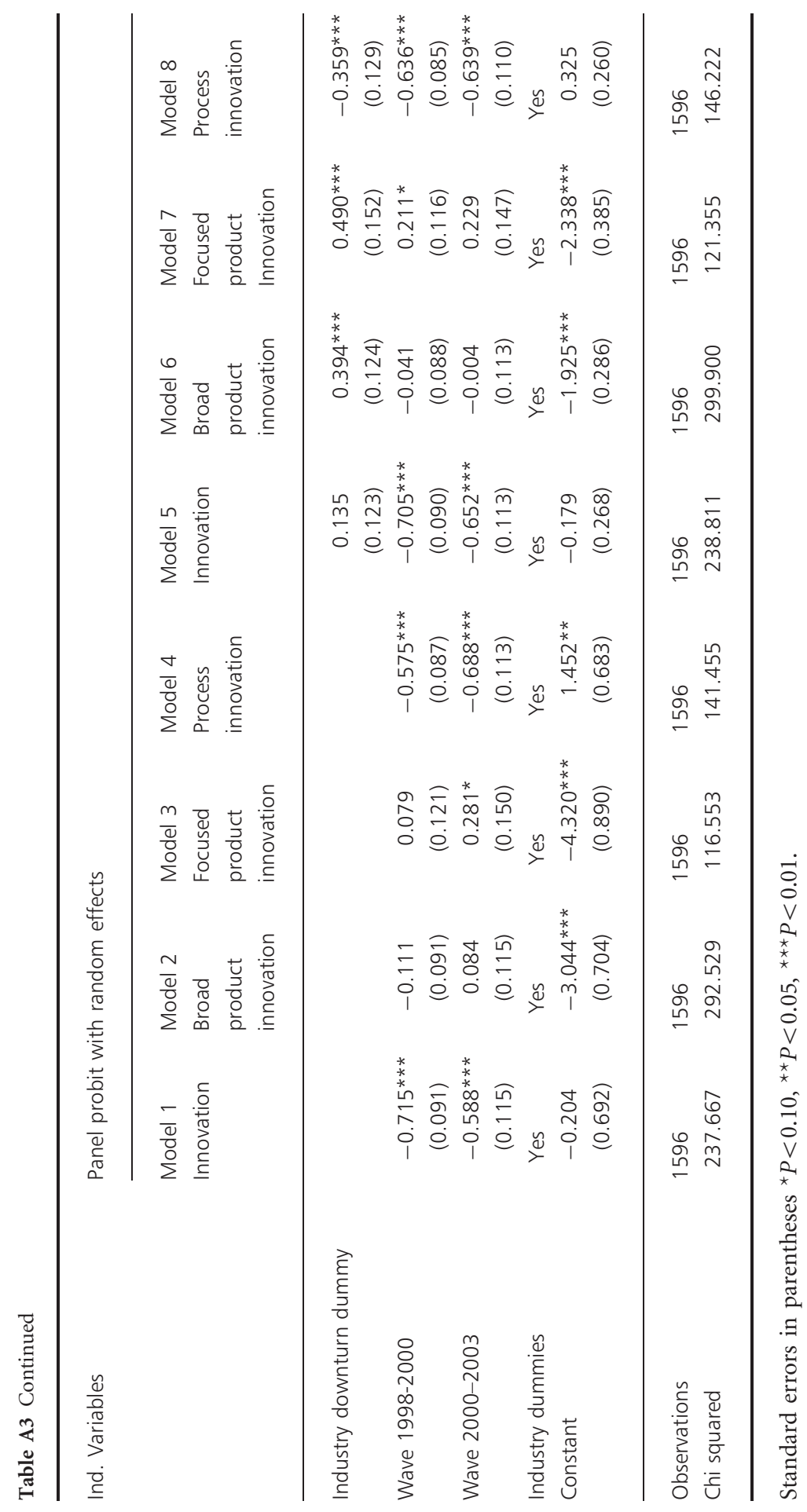




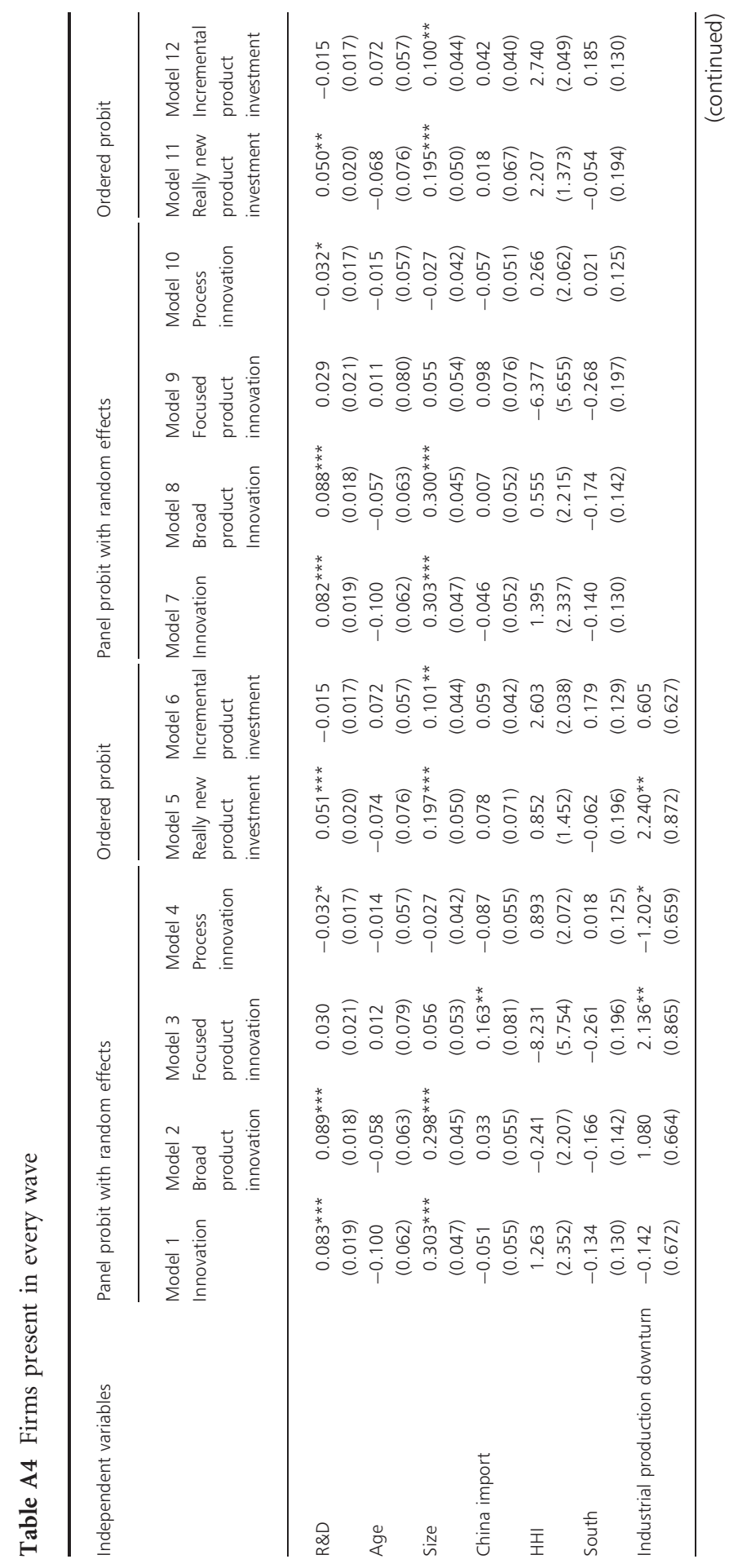




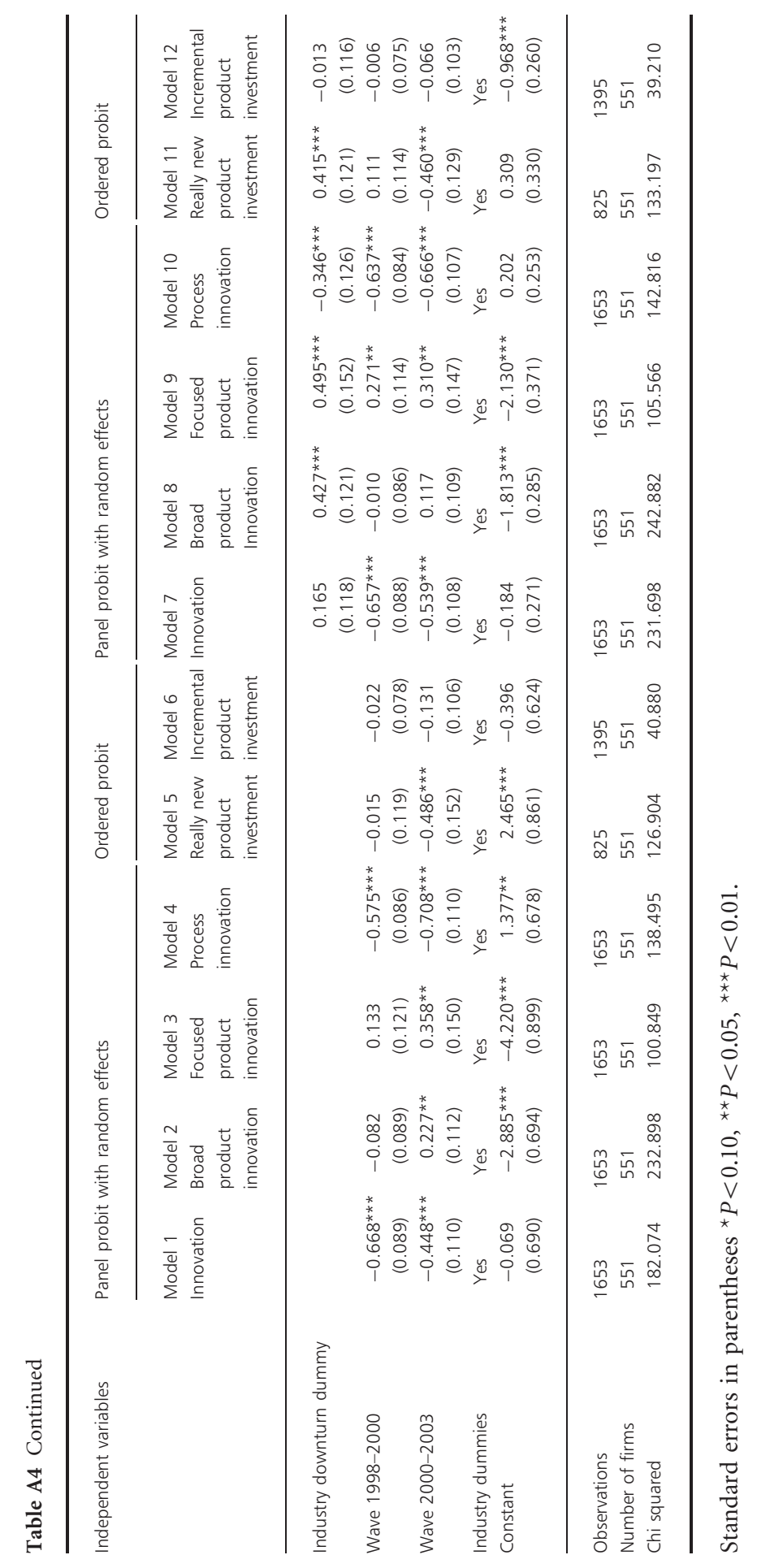

